\title{
Physicochemical and microbiological characteristics of urban aerosols in Krakow (Poland) and their potential health impact
}

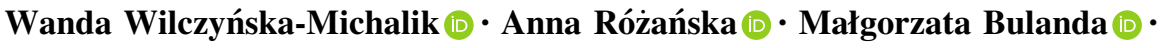 \\ Agnieszka Chmielarczyk (D) Bartłomiej Pietras (D) Marek Michalik (iD
}

Received: 31 May 2020/Accepted: 19 April 2021/Published online: 29 April 2021

(C) The Author(s) 2021

\begin{abstract}
Eight aerosol samples were collected in Krakow using a low-volume sampler in February and March 2019 during variable meteorological conditions and times of the day, to study their single particles' properties (size, morphology and chemical composition analyzed using a scanning electron microscope fitted with an energy-dispersive spectrometer) and microbiological characteristics. The content of particles of different chemical compositions larger than $2.5 \mu \mathrm{m}$ was low. Considering the number of the particles, submicron particles strongly dominated with
\end{abstract}

\footnotetext{
W. Wilczyńska-Michalik ( $₫) \cdot$ B. Pietras $(\bowtie)$ Institute of Geography, Pedagogical University in Kraków, ul. Podchorążych 2, Kraków, Poland e-mail: wanda.wilczynska-michalik@up.krakow.pl

B. Pietras

e-mail: bartlomiej.pietras@up.krakow.pl
}

A. Różańska · M. Bulanda · A. Chmielarczyk Chair of Microbiology, Faculty of Medicine, Jagiellonian University Medical College, ul. Czysta 18,

31-121 Kraków, Poland

e-mail: a.rozanska@uj.edu.pl

M. Bulanda

e-mail: malgorzata.bulanda@uj.edu.pl

A. Chmielarczyk

e-mail: agnieszka.chmielarczyk@uj.edu.pl

M. Michalik

Institute of Geological Sciences, Jagiellonian University, Ul. Gronostajowa 3a, 30-387 Kraków, Poland

e-mail: marek.michalik@uj.edu.pl a high content of ultrafine particles (nanoparticles). Tar ball-type particles were relatively common in the studied samples, while soot was the dominant component. Soot was present as small agglomerates composed of few particles, but also as bigger agglomerates. Metal-containing particles of various chemical characteristics were abundant, with transition metals commonly occurring in these particles. The physicochemical characteristics of aerosols indicate that despite a relatively low mass concentration, their adverse health impact could be very strong because of the high content of nanoparticles, the abundance of soot and other fuel combustion-related particles, and the high incidence of transition metalrich particles. Microbiological analysis was based on cultures on both solid and liquid agar. The MALDITOF method was used for species identification-for bacteria and fungi. Twelve different species of bacteria were isolated from the collected samples of aerosols. The most frequently isolated species was Gram-positive sporulating Bacillus licheniformis. The isolated mold fungi were of the genus Aspergillus.

Keywords Urban aerosol - Atmospheric particulate matter - Size and morphology of particles - Chemical composition of particles $\cdot$ Microorganisms in aerosols $\cdot$ Aerosol health impact 


\section{Introduction}

The percentage of urban populations is increasing rapidly. In 2018, the global urban population was $55.3 \%$ and it is expected to rise to $68.4 \%$ by 2050 (for more developed regions, $78.7 \%$ and $86.6 \%$, and for less developed regions, 50.6 and $65.6 \%$, respectively) (World Urbanization Prospects 2019). In Poland, the urban population constituted $60.05 \%$ of the total population in 2018 , with a slight decrease observed between 2000 and 2018 (i.e., 61.88\% in 2000 and $60.81 \%$ in 2010) (Population. Size and structure and vital statistics in Poland by territorial division .... 2019). High levels of air pollution are often noted in the urban environment, which results in a deterioration of environmental and health conditions (e.g., Kura et al. 2013). Urban areas play an important role in the emission of air pollutants (Jacobson 2012; Oke et al. 2017).

Lelieveld et al. (2015) estimated that 3.15 million premature deaths were related to outdoor PM2.5 globally in 2010. Taking into account the growth of urban populations and increasing air pollution concentrations, Lelieveld et al. (2015) estimated urban premature mortality to grow from 2.0 million in 2010 to 4.3 million by 2050 . Global excess mortality related to ambient air pollution is estimated at ca. 8.8 million annually, with a reduction in life expectancy of 2.9 years (Lelieveld et al. 2020).

Epidemiological studies indicate an increase in morbidity and mortality due to air pollution (Ayres et al. 2008; Dellinger et al. 2000; Lodovici and Bigagli 2011; Valavanidis et al. 2008). However, less is known about what physical and chemical properties of particles negatively impact on health (Ayres et al. 2008). To study these relationships, a detailed physicochemical characterization of aerosol particles is needed. Airborne microorganisms influence cloud development, atmospheric chemistry but also the spread of numerous diseases (e.g., Deguillaume et al. 2008; Burrows et al. 2009), and identifying them is important in the evaluation of health impact.

The high concentration of air pollution in Krakow has been a problem of great concern since the 1960s. However, a decrease in the concentration of particulate matter (PM) and $\mathrm{SO}_{2}$ was noted during the last 30 years (Wilczyńska-Michalik et al. 2016). High concentration of PM exceeding the legal limits is often recorded in Krakow, mainly in cold seasons. NOx and benzo(a)pyrene are also important components of air pollution in the city. PM in Krakow is characterized by the domination of fine particles with a high abundance of soot. Single-particle studies indicate that PM is derived from various sources, both natural (e.g., soil erosion) and anthropogenic (e.g., industrial emission, emission related to the combustion of solid fuels in household heating systems, vehicular emission and others) (Wilczyńska-Michalik and Michalik 2015; Wilczyńska-Michalik et al. 2015a, 2016). Microbiological characteristics of atmospheric aerosols in Krakow are almost unknown.

The aim of this study is to present the identification of microbiological components of aerosols and physicochemical characteristics of non-biological particulate matter (i.e., particles' size, morphology and chemical composition). Aerosols were collected in February and March 2019 in Krakow. Eight samples were collected during a two-week period, where the relatively short sampling period provided an opportunity to study the short-term variation in the samples' composition related to changing meteorological conditions. The sampling period represented the cold season (with relatively high PM concentration) and partly coincided with the period of increased seasonal incidence (seasonal flu and other diseases) (Martinez et al. 2019; Moriyama et al. 2020; Meldunki epidemiologiczne 2020).

Individual particle analysis based on scanning electron microscopy and energy-dispersive spectrometry (SEM-EDS) was applied for determination of physicochemical properties of PM. Because of the analytical method used, only selected culturable microorganisms were determined. The fraction of airborne bacteria detected by culture methods is usually less than 10\% (Burrows et al. 2009). Despite the limitations of the culture methods, the results are important in the studies of variation of the concentration of airborne bacteria with reference to seasons of the year, day and night, meteorological conditions (e.g., Bovallius et al. 1978; Fang et al. 2007; Dueker et al. 2017) or location in the town (Fang et al. 2007).

In this paper, we intend to point out those features of PM that are considered to be responsible for adverse effects on human health described in the literature, without detailed discussion on the interaction mechanism, or the possible environmental impacts. 


\section{Methods}

Sampling

Samples of total suspended particulate matter (TSP) were collected on polycarbonate membranes (pore size $0.1 \mu \mathrm{m}$; $47 \mathrm{~mm}$ in diameter) using a Life 1 One (Mega System) sampler. Microbiological and physicochemical analyses were performed on fragments of each membrane (ca. $80 \%$ of the surface for microbiological analysis and $20 \%$ for physicochemical study). The sampling details are presented in Table 1.

Scanning electron microscopy with energydispersive spectrometry

Fragments of polycarbonate membranes were coated with carbon and gold. Carbon-coated fragments of polycarbonate membranes were used mainly for chemical analyses (using the EDS method) and imaging using backscattered and secondary electrons signals. Gold-coated fragments were used mainly for imaging using secondary electrons signal. A field emission scanning electron microscope (FESEM) (Hitachi S-4700) was used for imaging. Secondary electrons and backscattered electrons (with a YAG detector) imaging modes were applied. The chemical composition of the particles was determined using energy-dispersive spectrometry (EDS) Noran NSS system. Quantitative determination of the content of chemical elements in dust particles was based on the standardless method. All results were recalculated to $100 \%$ (without carbon content).
Microbiological analysis

The polycarbonate membrane (47 $\mathrm{mm}$ in diameter), after the passage of 3500 or $4000 \mathrm{~L}$ of air, was placed on a sterile Petri dish, and a small piece with an area of $5 \times 5 \mathrm{~mm}$ was cut out using sterile scissors for chemical testing. Then, the filter was divided into two equal parts.

One part of the filter was put on agar medium with the addition of blood (Columbia agar) for determination of the number of bacteria in atmospheric air, used in other Polish studies previously (Burkowska-But et al. 2014)] (Becton Dickinson GmbH, Germany) for qualitative culture. The medium was incubated at $36 \pm 1{ }^{\circ} \mathrm{C}$ for $18 \mathrm{~h}$. The next day, each morphologically different bacterial colony was isolated from the medium and inoculated into a new medium for later identification. Species identification was conducted using the MALDI-TOF method (Bruker Daltonics, Germany).

The second part of the filter was placed in liquid medium (tryptic soy broth [TSB]) and pre-incubated at $36 \pm 1{ }^{\circ} \mathrm{C}$ for $18 \mathrm{~h}$. After this, the portion of $100 \mu \mathrm{l}$ was taken from the broth and spread on agar medium (tryptic soy agar [TSA]) and blood agar medium (Columbia agar) using the decimal serial dilution method. The colonies obtained by quantitative culture were counted, and the results were given as colonyforming unit per milliliter (CFU/ml). The colonies cultured and isolated in the quantitative part of the test were also identified using the MALDI-TOF method.
Table 1 Sampling details

Campus-III Campus of the Jagiellonian University, 3a Gronostajowa Str., southern part of the city Friedleina-22 Friedleina Str., northern part of the city

\begin{tabular}{llll}
\hline Date (dd/mm/yyyy) & Sampling time & Volume of air (l) & Localization \\
\hline $28 / 02 / 2019$ & $9: 00-16: 30$ & 3500 & Campus \\
$1 / 03 / 2019$ & $8: 00-15: 45$ & 3500 & Campus \\
$4 / 03 / 2019$ & $8: 30-16: 20$ & 3500 & Campus \\
$5 / 03 / 2019$ & $8: 35-16: 40$ & 3500 & Campus \\
$9 / 03 / 2019$ & $15: 25-24: 20$ & 4000 & Friedleina \\
$10 / 03 / 2019$ & $12: 00-19: 40$ & 4000 & Friedleina \\
$11 / 03 / 2019$ & $15: 10-23: 35$ & 4000 & Friedleina \\
$13 / 3 / 2019$ & $8: 30-17: 50$ & 5000 & Campus \\
\hline
\end{tabular}




\section{Meteorological situation during sampling}

The analyzed material contained a series of eight samples collected in the period from February 28 to March 13, 2019 (Table 1).

The temperature, humidity, wind speed and direction, insolation and cloud cover, together with the PM10 and PM2.5 concentrations measured at the State Environmental Monitoring Stations of the Provincial Inspectorate of Environmental Protection in Krakow are presented in Table 2 . The relatively high wind speeds during the sampling period caused rather low concentrations of PM.

The average wind speed during the sample collection varied from 4.5 to $9.7 \mathrm{~m} / \mathrm{s}$, while the average PM10 concentration during the sample collection was between 12.0 and $63.2 \mu \mathrm{g} / \mathrm{m}^{3}$. It is astonishing that during the collection of the samples on February 28, 2019, with a relatively strong wind (average value: $9.7 \mathrm{~m} / \mathrm{s}$ ) and low humidity, the concentration of PM10 was very high (average value: $53.9 \mu \mathrm{g} / \mathrm{m}^{3}$ ) (Table 2).

During the sampling period, in most cases, the weather was shaped by low-pressure systems, and among other dates, from March 9 to 11, 2019, the highest relative humidity values, favoring the formation of secondary aerosols (Zang et al. 2019), were recorded. The increase in relative humidity was probably related to the passage of an occluded atmospheric front system during the above-mentioned period. Significant activity of zonal circulation (western inflow) and, at the same time, the increase in pressure gradient connected with the passage of the front with wind speed and shower rain episodes, caused a significant dispersion and leaching of dust pollution from the atmosphere. As a result, relatively low dust concentration values were observed in the discussed period. However, the highest concentration of dust was observed on February 28, 2019, when Poland was under the influence of a trough associated with a quasi-stationary low over the northern part of Russia, and March 1, 2019, when the country was in a weak-gradient area of low pressure. Thus, on these dates, the north and northwest inflow of relatively dry and cold air masses dominated.

\section{Results and discussion}

Physicochemical characteristics of PM

\section{Particle size}

The method of sampling allowed the collection of the total suspended dust. Careful investigation of the samples indicated that only single particles larger than $10 \mu \mathrm{m}$ are present. Plant debris fragments are usually present as fibrous material up to $0.5 \mathrm{~mm}$ long (Fig. 1a, 1b). Pollen grains are also often bigger than $10 \mu \mathrm{m}$ (Fig. 1c). Aluminosilicate grains larger than $10 \mu \mathrm{m}$ are scarce (Fig. 1d). The number of particles sized between 10 and $2.5 \mu \mathrm{m}$ is very low. Their form of occurrence and the chemical composition of particles within this grain size are diversified. Aggregates of aluminosilicate particles (Fig. 2a, b) and aggregates of soot particles (Fig. 2c, 2d) dominate in this grain size category. Elongated $\mathrm{Ca}$ sulfate or $\mathrm{Ca}$ and $\mathrm{Mg}$ carbonate grains occur rarely (Fig. 2e, 2f). Single particles in aluminosilicates aggregates differ in chemical composition. Ca sulfates occur in some of the aggregates as grains or bind them.

A dominant number of particles in all the studied samples are sized below $1 \mu \mathrm{m}$ (Fig. 3 and 4). The dominance of PM1 in the PM in Krakow was pointed out by Wilczyńska-Michalik et al. (2015b). The number of particles below $0.1 \mu \mathrm{m}$ (ultrafine particles) is very high in the studied samples (Fig. 5). Ultrafine particles (below $0.1 \mu \mathrm{m}$ or $100 \mathrm{~nm}$ ) are often reported as nanoparticles, but in the case of aerosols, $50 \mathrm{~nm}$ is also considered as a boundary of nanoparticles. Kumar et al. (2010) suggested using the $<300 \mathrm{~nm}$ boundary for atmospheric nanoparticles, because this size range includes more than $99 \%$ of the total particle number concentration in ambient atmosphere. Scanning electron microscope (SEM) observations indicated that a similar particle size distribution is noted in Krakow.

The content of PM1 or PM0.1 in Krakow is not measured systematically. Concentration of PM2.5 is measured at three stations from the State Environmental Monitoring system. Considering the average concentration of PM2.5 and PM10 measured in Krakow in cold (1 November-31 March; average month temperature is below $0{ }^{\circ} \mathrm{C}$ ) and warm (1 April31 October; average month temperature is above $0{ }^{\circ} \mathrm{C}$ ) periods, it is possible to calculate that PM2.5 fraction constitutes $72.88-76.22 \%$ in the cold season and 


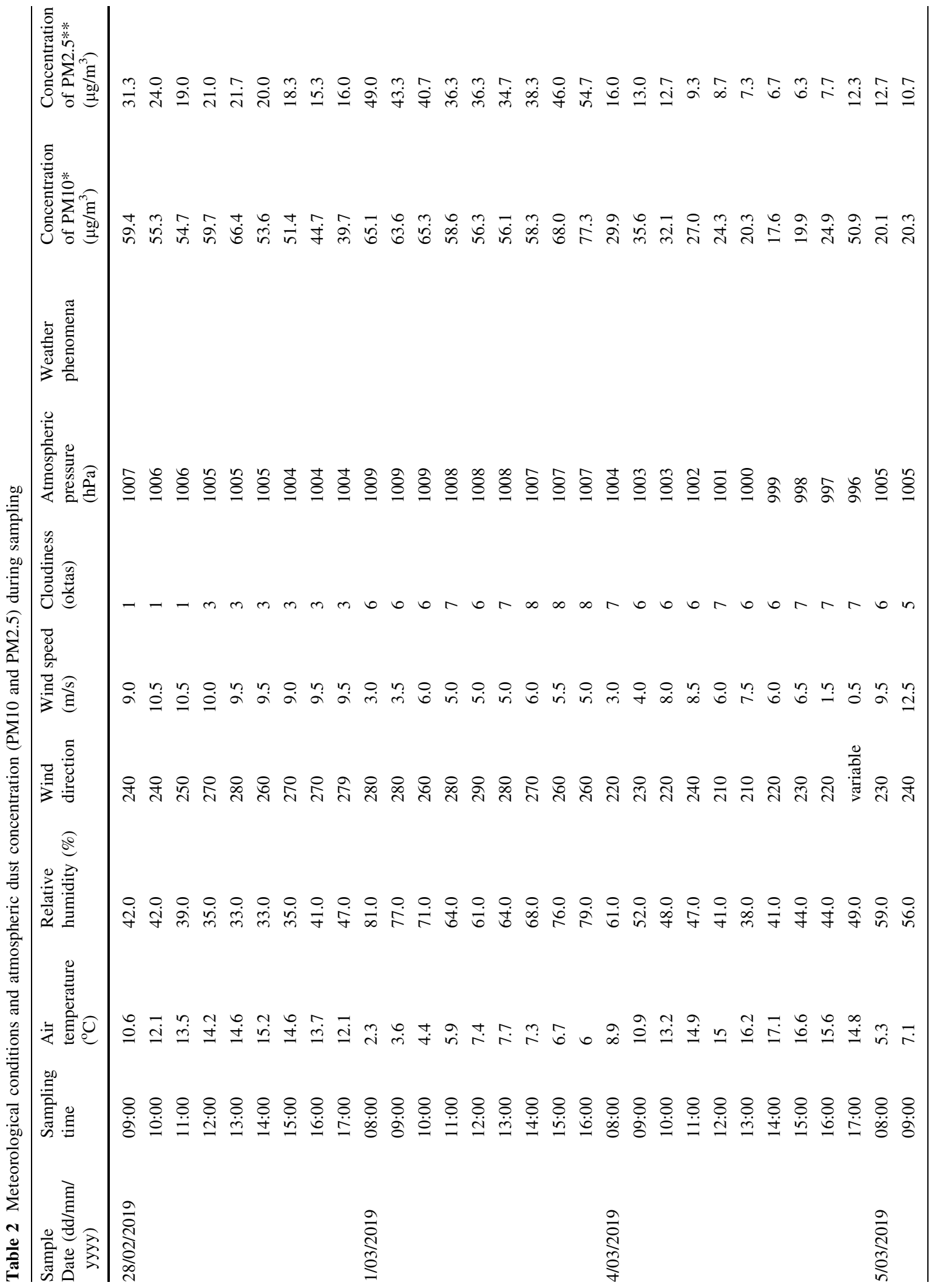




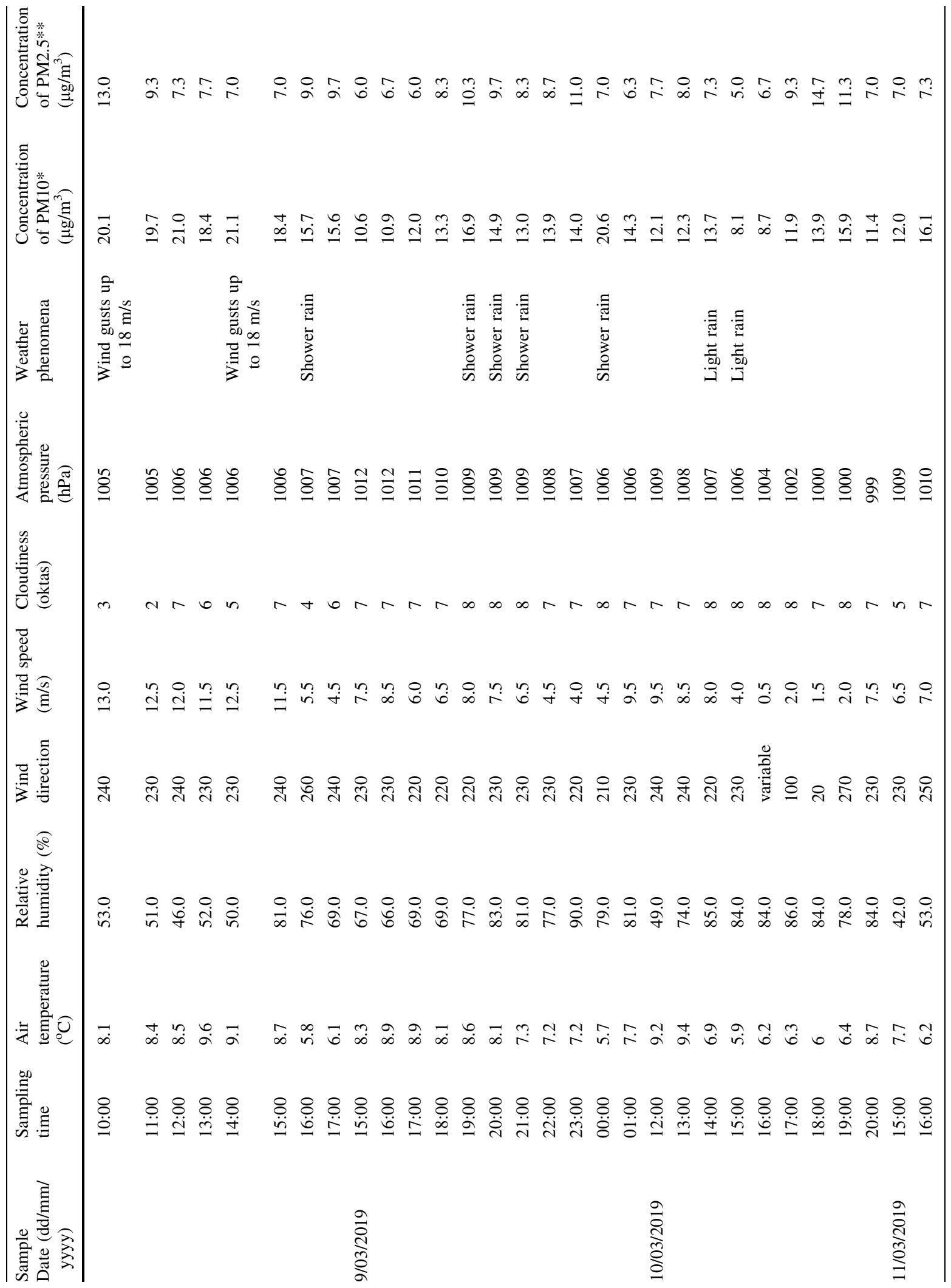




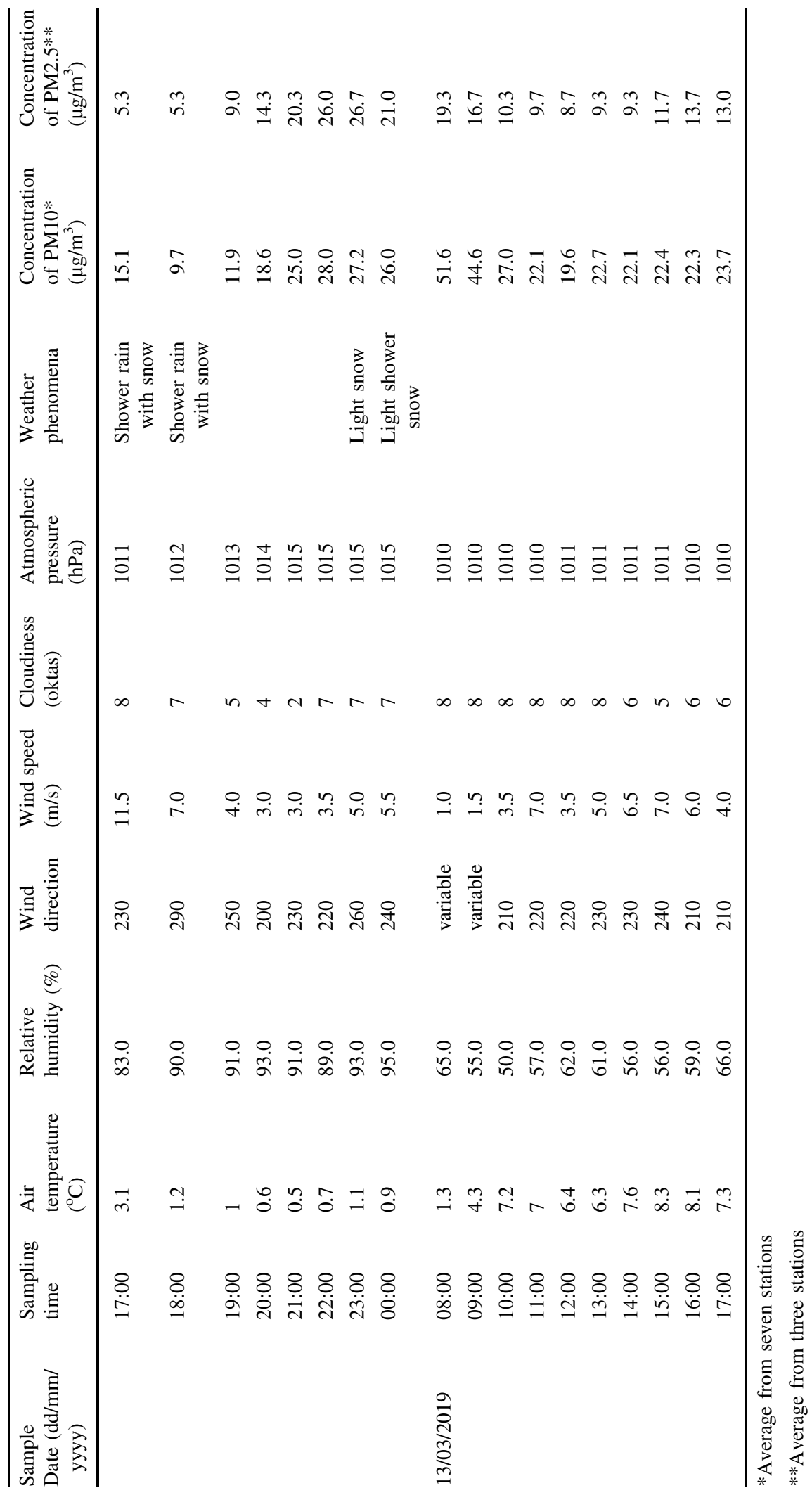



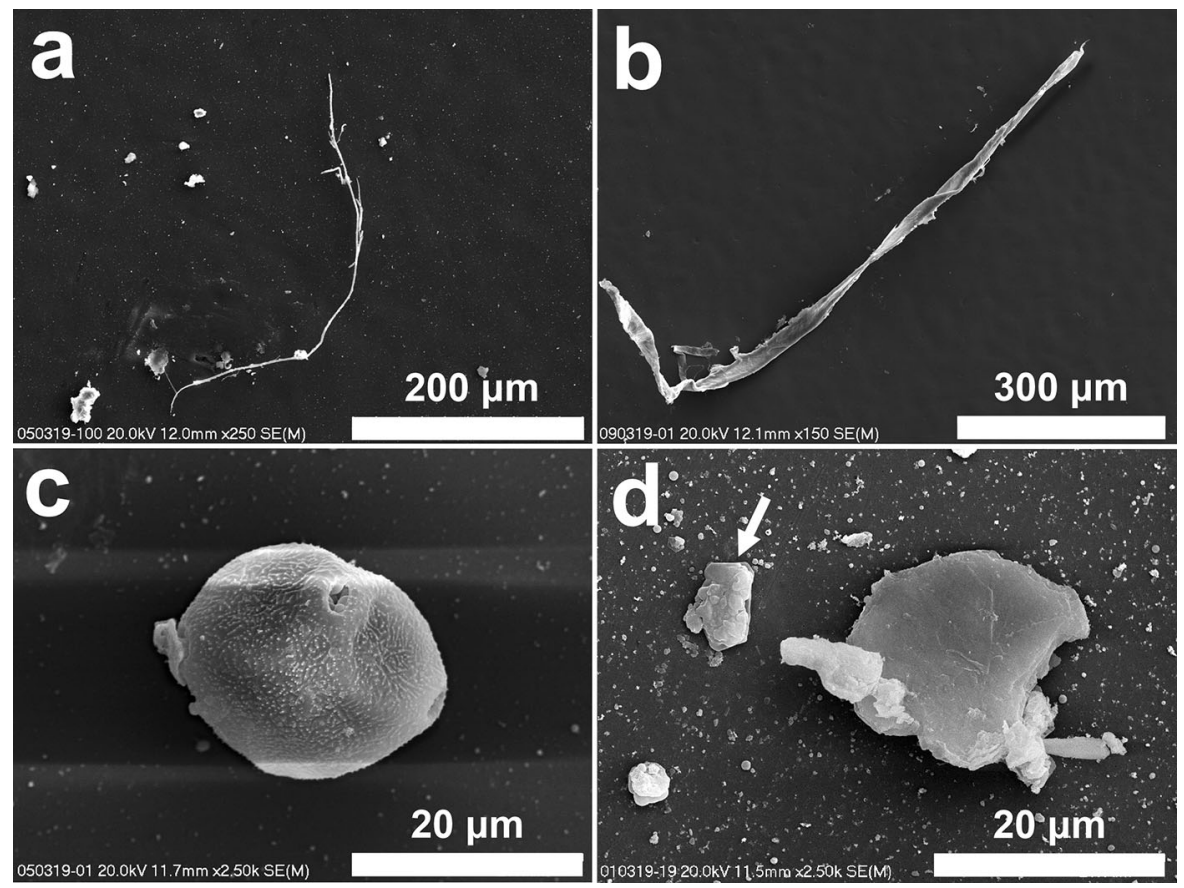

Fig. 1 Coarse particles in atmospheric dust (SEM images). a and b. Fibrous plant debris. c. Pollen grain. d. Big aluminosilicate grain (containing $\mathrm{Fe}, \mathrm{Mg}$, $\mathrm{Ti}, \mathrm{Ca}, \mathrm{K}, \mathrm{Na}$ ); smaller particle (arrow) is composed of $\mathrm{Cl}$ and $\mathrm{Na}$

56.11-67.03\% of PM10 in the warm season during the 2008-2019 period. There are only limited data related to the particle number concentration in the atmosphere in Krakow. According to Bogacki et al. (2010), the number of particles per $1 \mathrm{~m}^{3}$ varied from negligible to more than 400000 in relation to temperature within a 24-h period.

The common opinion is that the percentage of fine and ultrafine particles in air pollution is growing and will continue to increase along with changing emission sources. The results of the modeling presented by Keogh et al. (2014) indicated that it is possible to expect a 100-fold growth of the particle number concentration in the atmosphere, together with a $31-36 \%$ decrease of mass concentration in Southeast Queensland, Australia, up to 2026.

The concentration of nanoparticles in the urban atmosphere (both natural and anthropogenic) is higher than in other environments (Buseck and Adachi 2008). Anthropogenic nanoparticles in the urban environment originate from different sources with an important share of particles from vehicular engines (Kumar et al. 2010, 2011a; Morawska et al. 2009). Nanoparticles in the atmosphere could be primary and secondary. In the urban environments, products of fuel combustion in vehicle engines are the main source of secondary nanoparticles (Morawska et al. 2009). Kumar et al. (2011b) discussed the importance of the measurement of the number and the number-size distribution of nanoparticles in the urban atmosphere and the technical problems related to the regulations and standardization of methods for monitoring. The lung deposited surface area (LDSA) of PM concentration, or the lung deposited surface area size distribution, is considered as a relevant metric for the negative health effects of aerosol particles (Kuuluvainen et al. 2016).

Outdoor PM2.5 is considered as the fifth leading risk factor for death in the world (Schraufnagel et al. 2019). Ultrafine particles cause a greater inflammatory response than fine particles (Donaldson and Stone 2003). The effect is enhanced by the presence of ozone (Oberdörster 2001). Oberdörster et al. (2005) considered nanotoxicology as an emerging discipline because of the great hazard to the biosphere and human health related to exposure to nanoparticles. Nanoparticles are significantly more active biologically than larger particles of the same chemical composition, because of the much greater surface area 


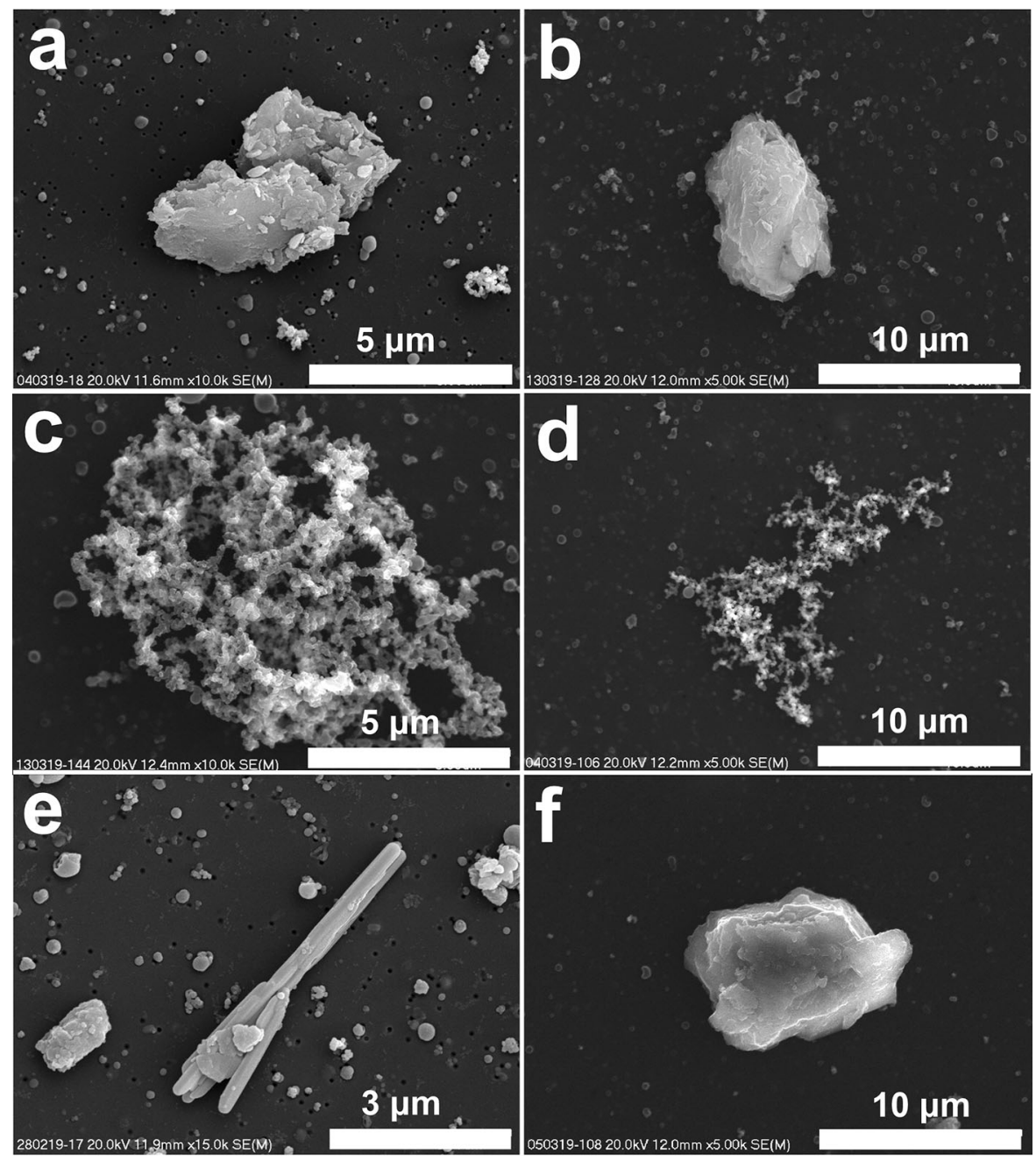

Fig. 2 Particles of the size from 2.5 to $10 \mu \mathrm{m}$ (SEM images). a and b. Aluminosilicate aggregates. c and d. Aggregates of soot particles. e. Elongated $\mathrm{Ca}$ sulfate grain. f. $\mathrm{Ca}$ and $\mathrm{Mg}$ carbonate

per mass. The toxicology of inhaled nanoparticles was discussed by Bakand et al. (2012).

\section{Carbonaceous products of fuel combustion}

Carbonaceous products of fuel combustion dispersed as aerosol particles in the atmosphere influence climate, visibility and health. Their definitions (i.e., tar balls, black carbon and soot) were presented by Buseck et al. (2012). We use the term 'soot' for carbon spherical particles below $100 \mathrm{~nm}$ in size, which are often aggregated in chain-like or other forms, and tar ball-type particles for larger, single spherical carbondominated particles around 200-1000 nm in size.
Tar ball-type particles Tar ball-type particles in aerosols in Krakow have not been described in detail previously. Their abundant presence was noted in all samples collected in February and March 2019 (Fig. 6). Usually, tar balls are interpreted as a product of biomass burning (Posfai et al. 2004; Adachi and Buseck 2011; China et al. 2013; Adachi et al. 2019). In general, it is assumed that the relative abundance of tar balls increases with the age of the smoke (Adachi and Buseck 2011). Zhang et al. (2018) and Makonese et al. (2019) described the formation of spherical organic particles during residential coal combustion. Makonese et al. (2019) noticed that the size of the spherical particles formed during coal combustion varied within a broad range up to 'giant' 


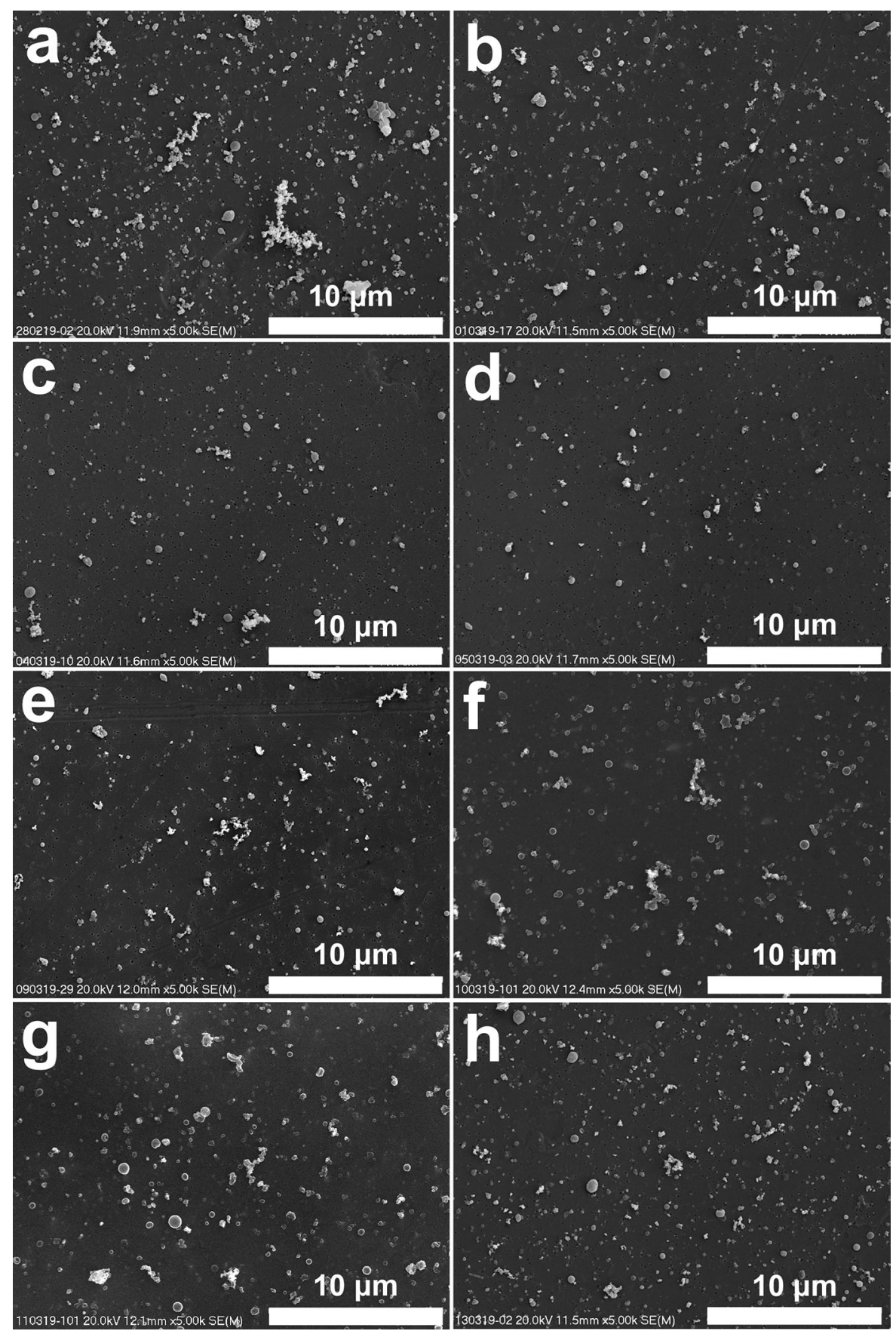

Fig. 3 Atmospheric particulate matter on filter (SEM images, magnification $5000 \mathrm{x}$ ). Dominance of particles below $1 \mu \mathrm{m}$. High content of soot and spherical tar ball-type particles. Very low content of particles above $1 \mu \mathrm{m}$. Images represent different

ones (larger than $2 \mu \mathrm{m}$ ). Tar balls were described as a component of the urban aerosol in the winter period in China (Hu et al. 2012). Taking into account the samples: a-28/02/2019; b-01/03/2019; c-04/03/2019; d05/03/2019; e-09/03/2019; f-10/03/2019; g-11/03/2019; h- $13 / 03 / 2019$

number of particles in PM2.5, tar balls constitute 9.0-12.9\%, where a higher concentration was noted during cloudy days (Hu et al. 2012). Tar balls collected 


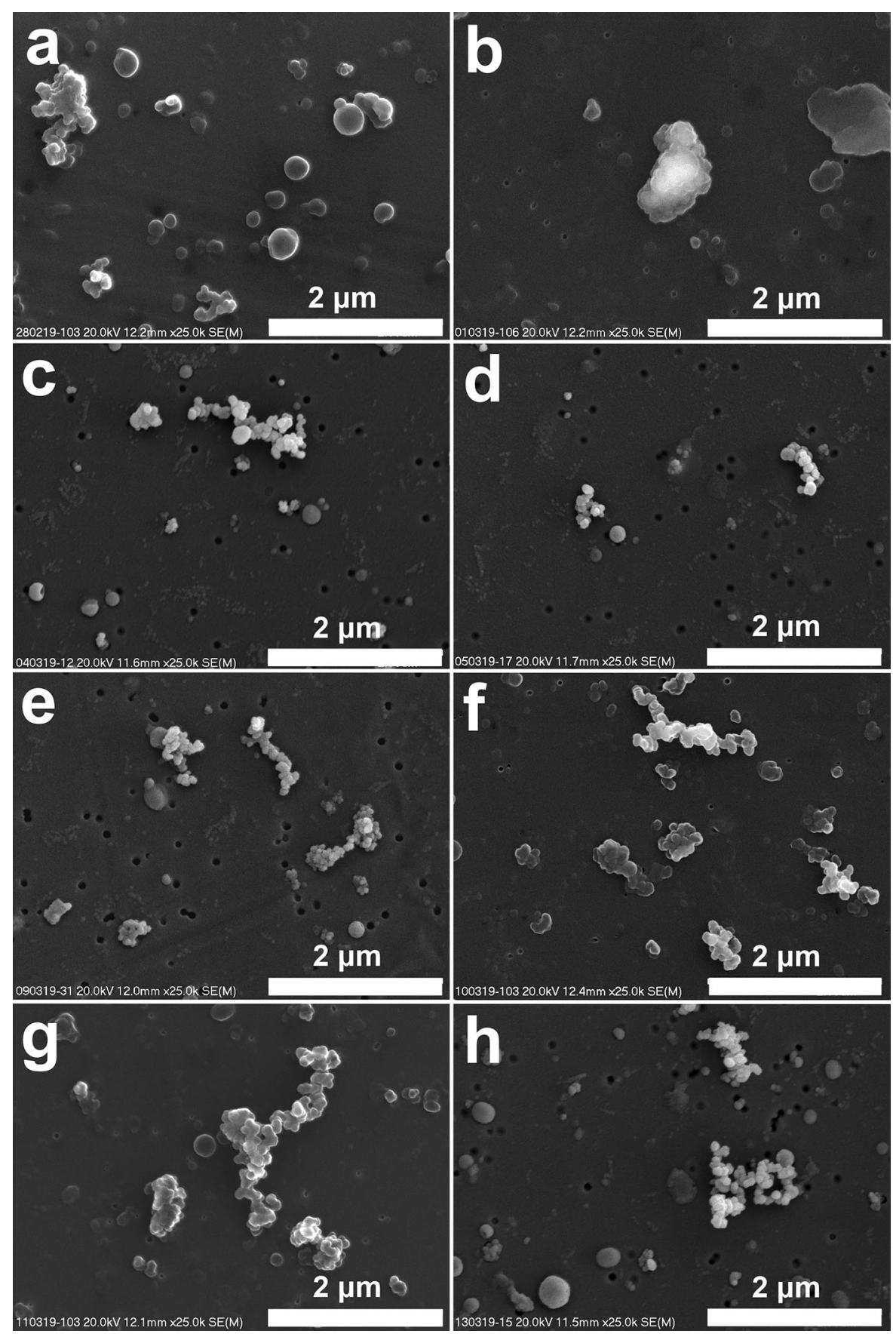

Fig. 4 Atmospheric particulate matter on filter (SEM images, magnification $25000 \mathrm{x}$ ). Soot and tar ball-type particles below $1 \mu \mathrm{m}$. Images represent different samples: a-28/02/2019; b-

01/03/2019; c-04/03/2019; d-05/03/2019; e-09/03/2019; f-10/03/2019; g-11/03/2019; h-13/03/2019

in Krakow were not analyzed using a transmission electron microscope, and we could not prove that they are amorphous (cf. Tóth et al. 2014). As mentioned, the size of the tar balls varies within a broad range

from around $200 \mathrm{~nm}$ to $1 \mu \mathrm{m}$ (Fig. 6a-c). This indicates that the typical size of tar balls noted in aerosols in Krakow is larger than described in the literature, both for natural and experimentally 


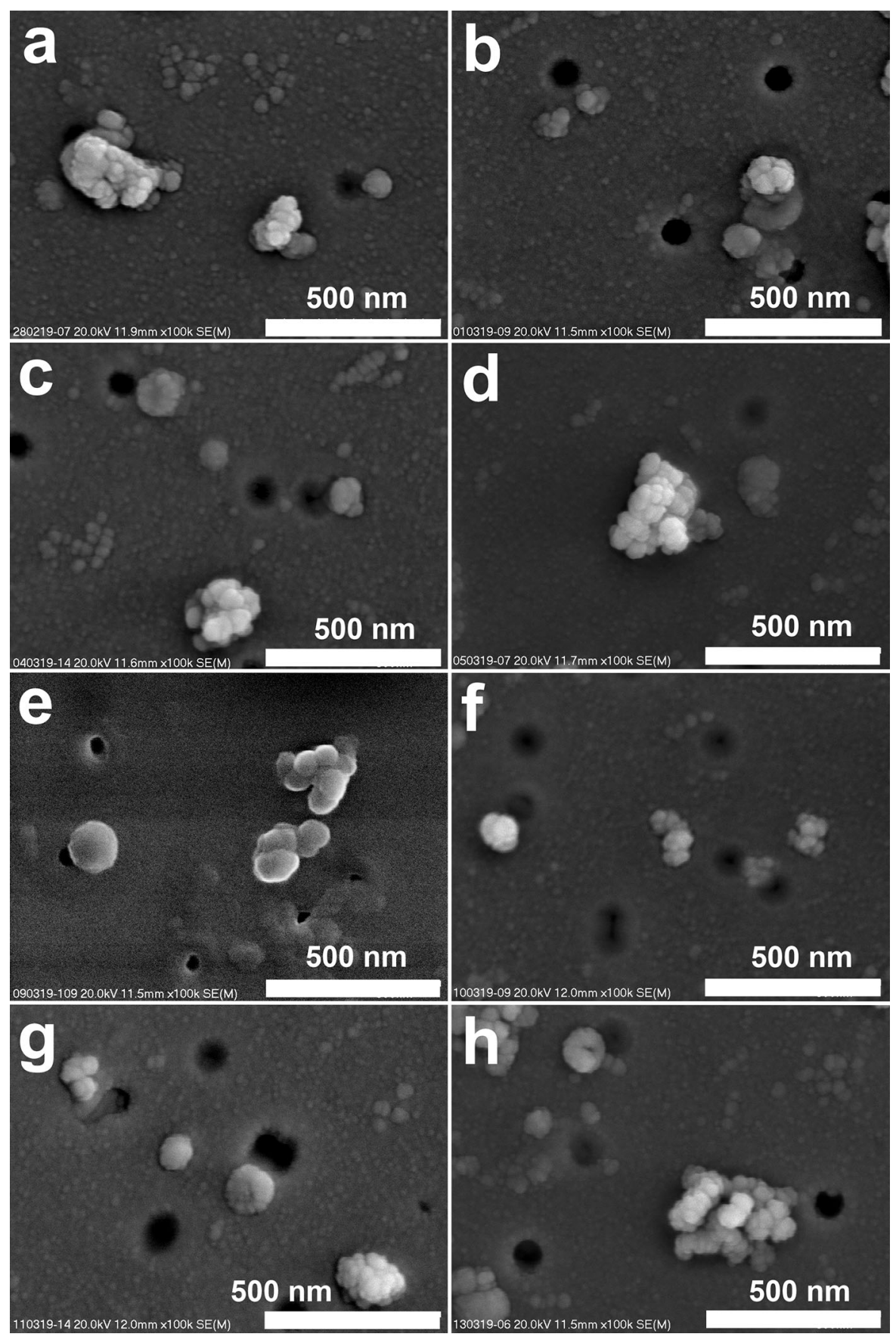

Fig. 5 Particles on filters (SEM images, magnification 100000 $\mathrm{x}$ ). Soot and single tar ball particle (e) around and below $100 \mathrm{~nm}$. Images represent different samples: a-28/02/2019;

b-01/03/2019; c-04/03/2019; d-05/03/2019; $\mathbf{e}-09 / 03 /$ $2019 ; \mathbf{f}-10 / 03 / 2019 ; \mathbf{g}-11 / 03 / 2019 ; \mathbf{h}-13 / 03 / 2019$

produced forms from biomass combustion, while the size can be partially related to the type of biomass burned (Adachi and Buseck 2011; Pósfai et al. 2004; Tóth et al. 2014).

The presence of large tar ball particles can indicate their origin in the coal combustion process. Tar balls usually occur as single spheres, but sometimes smaller hemispherical forms are joined to larger spheres 


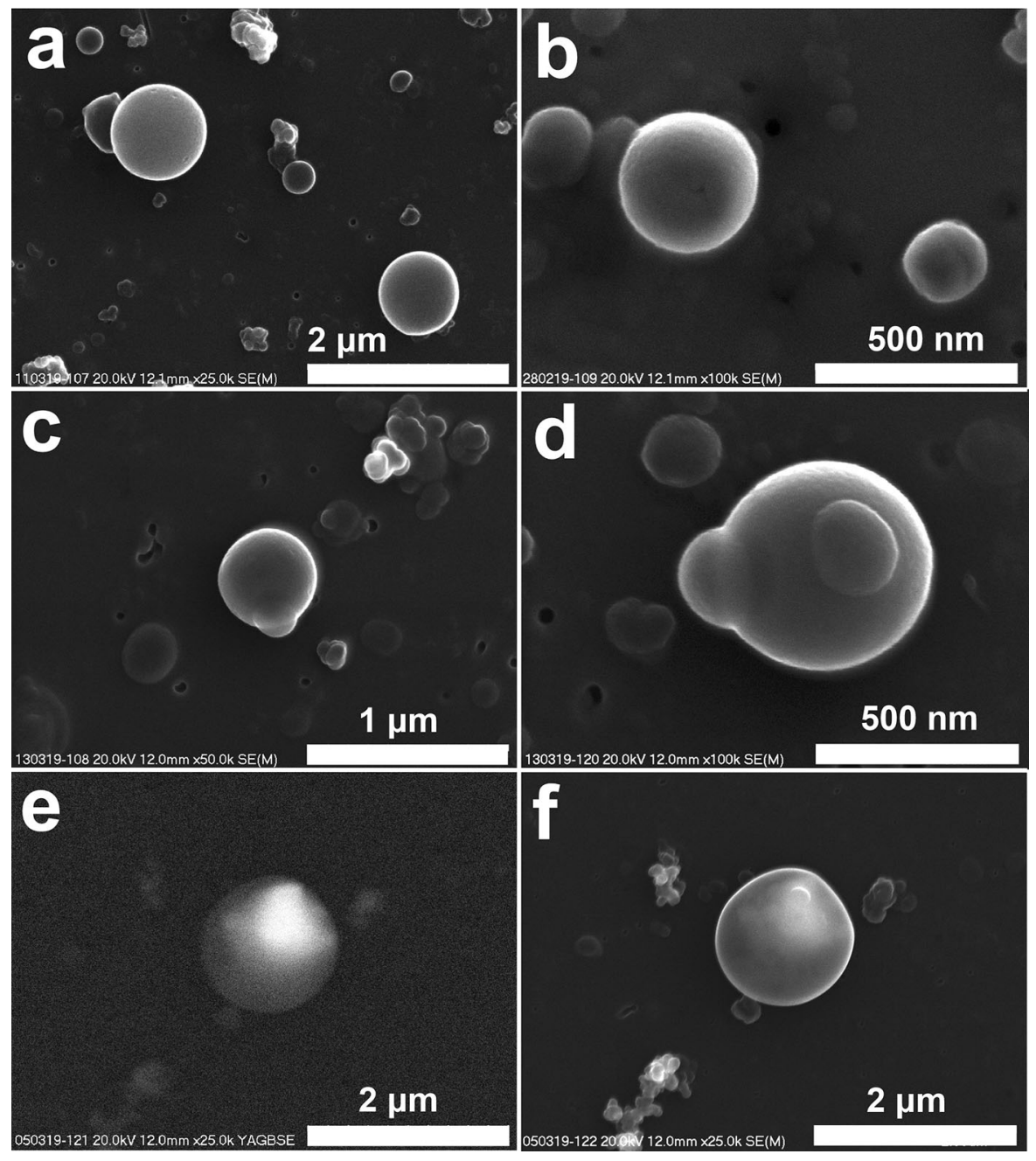

Fig. 6 Tar ball-type particles of different size and morphology (SEM, a to d-secondary electrons images). a to c. Tar balls of the size from $200 \mathrm{~nm}$ to $1 \mu \mathrm{m}(\mathbf{a}-11 / 03 / 2019$; $\mathbf{b}-28 / 02 / 2019$; c-13/03/2019), c and d. Tar ball-type particles-smaller hemispherical forms joined to larger spheres (d-13/03/2019),

(Fig. 6c, d). The chemical composition of the analyzed tar balls is dominated by $\mathrm{C}$, with low content of $\mathrm{O}$, which can be considered as typical for tar balls (Pósfai et al. 2004; Tóth et al. 2014). In the analyzed tar balls, low content of $\mathrm{S}, \mathrm{K}$ and $\mathrm{Si}$ is common, which was often noted (e.g., Toth et al. 2014). In several tar balls, Ba and $\mathrm{S}$ were noted (Fig. 6e-f), and in one tar ball, there was a low content of $\mathrm{Zn}$. According to Zhang et al. (2018), spherical organic matter particles formed during coal combustion contained more Si than tar balls from biomass combustion. $\mathrm{Ba}$ and $\mathrm{S}$ occur often in products of coal burning (e.g., Wilczyńska-

e and f. Tar ball-type particle with elevated content of Ba and S (e-backscattered electrons image; f-secondary electrons image). Brighter zones (e) are enriched in $\mathrm{Ba}$ and $\mathrm{S}$. (e, f-05/ 03/2019)

Michalik et al. 2019), but are also present in ash from biomass burning (e.g., Wilczyńska-Michalik et al. 2018). Therefore, it seems that the content of $\mathrm{Ba}$ and $\mathrm{S}$ in tar balls cannot be considered as an indicator of their source.

The small size and composition of tar balls (dominance of aromatic compounds; Li et al. 2019) indicate their potential hazardous impact on human health. Negative health impact of polycyclic aromatic hydrocarbons from incomplete combustion related to their carcinogenic toxicity is discussed by numerous authors (e.g., Shrivastava et al. 2017). 
Soot particles Soot is a common component of atmospheric pollution that intensively absorbs solar and terrestrial radiation, the second factor after $\mathrm{CO}_{2}$ that causes global warming (Wang et al. 2016).

Soot is a common component of aerosol particles collected in Krakow. It can be present as single particles (around $100 \mathrm{~nm}$ in size or smaller) (Fig. 7a, b), although agglomerates occur more often (Fig. 7b, c, d). These agglomerates could be small, composed of several particles (Fig. 7b, c), or larger, containing numerous particles (Fig. 7d). Soot occurs as lacey and compact agglomerates (Fig. 7e, f). Loosely packed agglomerates reach $20 \mu \mathrm{m}$. The formation of compact forms is related to aging, due to condensation and evaporation of water on their surface (e.g., Zuberi et al. 2005). Soot identification in the studied samples was based on the morphology of particles or agglomerates (and confirmed by C-dominated chemical composition). The morphology of soot (particle size and the shape of agglomerates) cannot be used for source identification (Michalik et al. 2016).

The health hazards of soot (e.g., high carcinogenic, mutagenic and allergenic potential) are discussed in numerous papers (e.g., Niranjan and Thakur 2017; Saenen et al. 2017; Shiraiwa et al. 2012; Su et al. 2008). Soot originates from incomplete combustion of

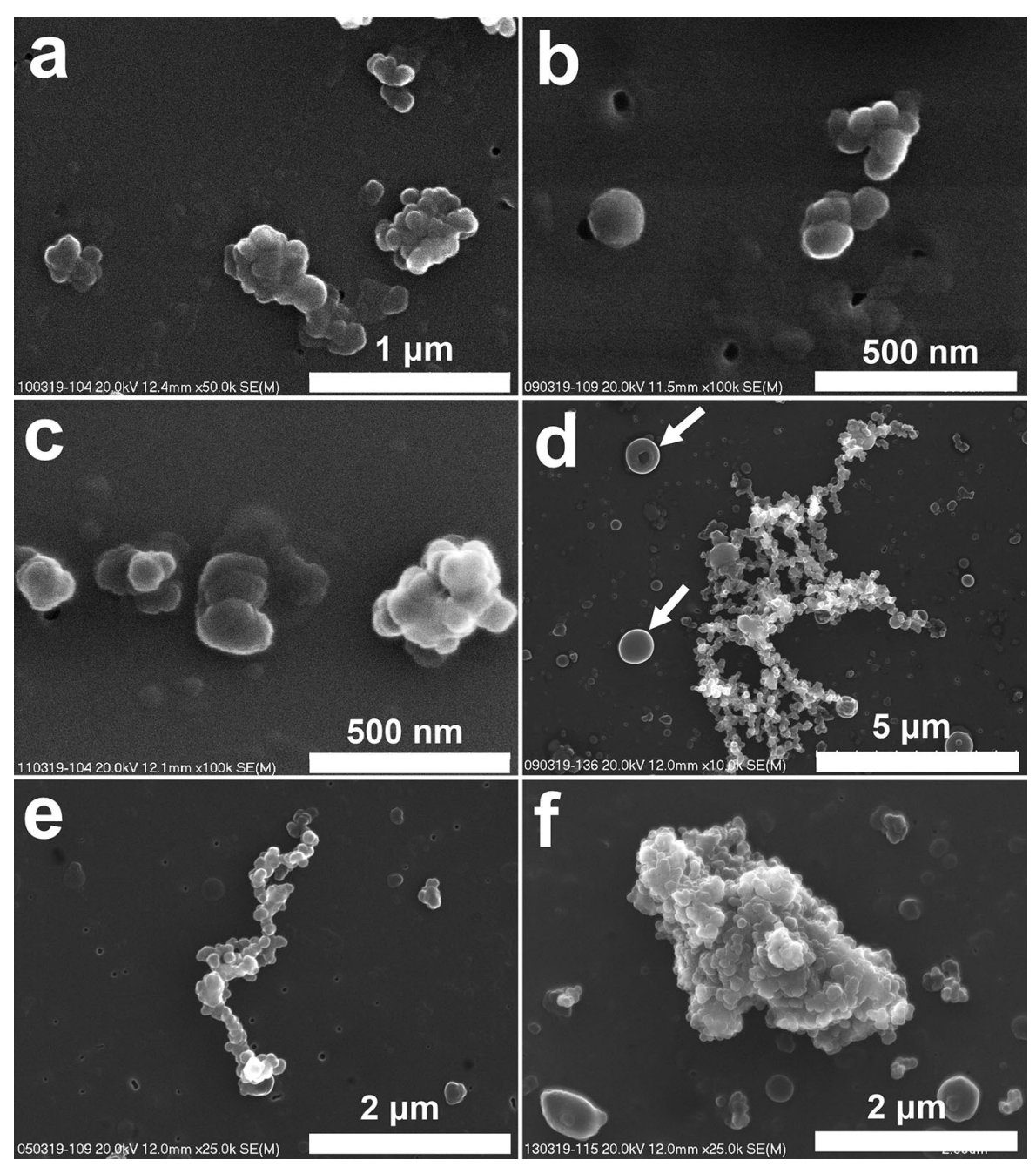

Fig. 7 Soot particles (SEM, secondary electron images). a to c. Soot-small agglomerates composed of several particles and single particles (a-10/03/2019; b-09/03/2019; c-09/03/ 2019), d. Loosely packed agglomerate of numerous soot

particles; tar balls (arrows) (09/03/2019), e. Lacey-type agglomerate of soot particles (05/03/2019), f. Compact agglomerate of soot particles $(13 / 03 / 2019)$ 
fuels, and it contains various amounts of volatile or semi-volatile organic substances (including polycyclic aromatic compounds, alkenes and carboxylic acids) and metals (Kelly and Fussell 2015; Niranjan and Thakur 2017; Shiraiwa et al. 2012). The characteristics of soot (i.e., the content of organic substances) are related to the type of fuel and combustion conditions (Atiku et al. 2016). Su et al. (2008) determined that the cytotoxic and inflammatory potential of soot from Euro IV is higher than soot from old diesel engines, mostly due to the smaller particle size (the high abundance of chemically reactive edges and the presence of surface functional groups). Also, Stone et al. (1998) concluded that ultrafine black carbon (soot) exhibits a stronger effect on health than fine black carbon. Soot particles, because of their small size, can penetrate deeply into the human body; for example, Bové et al. (2019) described the presence of soot in human placenta, while Saenen et al. (2017) recognized airborne carbon (soot) particles in the urine of children, which indicates the translocation of these ultrafine particles from the lung to the circulation and then to the urine.

The content of metals in individual soot particles is rather low, but taking into account the number of particles, the health impact could be significant. Using the SEM-EDS method, it was possible to measure the $\mathrm{Si}, \mathrm{Na}$ and $\mathrm{S}$ content in some particles. It is possible to thus assume that the cumulative effect of soot and other particles can be important. The synergistic adverse health effects of soot and Fe-rich particles were described by Zhou et al. (2003).

\section{Metals in PM}

Metals contained in atmospheric PM exert various health effects (Cakmak et al. 2014; Chapman et al. 1997; Fortoul et al. 2015; Gonet and Maher 2019; Maher 2019). The content of metals in atmospheric PM was analyzed by numerous authors using different methods. Metal-containing particles differ significantly in chemical and physical characteristics (Sanderson et al. 2014). Rogula-Kozłowska et al. (2014) compared the mass concentration and chemical composition of PM2.5 samples collected in urban sites (Katowice and Gdańsk) and a regional background site (Diabla Góra) in Poland. Pastuszka et al. (2010), Rogula-Kozłowska and Klejnowski (2013), RogulaKozłowska et al. (2015) and Samek et al. (2017) presented results of analyses (including the chemical composition) of PM from different urban sites in southern Poland. Krzemińska-Flowers et al. (2006) measured the concentration of trace elements in PM in three sites in the Polish city of Łódź.

The concentration of four metals considered to be toxic $(\mathrm{Pb}, \mathrm{As}, \mathrm{Cd}, \mathrm{Ni})$ is measured in PM10 within the frame of the European monitoring system. Data from European countries in 2017 indicated that the target value for As was exceeded in seven (three in Poland) out of 645 stations, for Cd in two stations out of 670 and for $\mathrm{Ni}$ in five stations out of 649 , while $\mathrm{Pb}$ was below the target value in all the data from 642 stations (Air Quality in Europe-2019 report).

Analyses of metals contained in single particles of atmospheric dust in Poland are relatively scarce. Wawroś et al. (2003) determined particles rich in Fe, $\mathrm{Cu}, \mathrm{Ti}, \mathrm{Cr}, \mathrm{Zn}$ and $\mathrm{Ni}$ in samples collected in Katowice, while Wilczyńska-Michalik and Michalik (2015) and Wilczyńska-Michalik et al. (2015a, b) described particles rich in metals in PM from Krakow.

The details of the single-particle analysis of aerosol samples collected in February and March 2019 in Krakow indicate that both the content and characteristics of metal-rich particles in all samples are similar. However, the number of analyzed particles was too low for statistically valid determination of the content of different groups of particles. Particles containing different metals, except for alkaline and alkaline-earth metals (but including $\mathrm{Ba}$ ), and some metalloids will be discussed here.

The most common group is dominated by a relatively high content of metals and oxygen. Generally, it is difficult to precisely determine the content of oxygen in metal-rich particles using the EDS method, but most of the particles in this group can be considered to be oxides or oxide-dominated. Usually, $\mathrm{Fe}$ is a dominant metal with the content above $50 \mathrm{wt} \%$. $\mathrm{Fe}$ is often accompanied by $\mathrm{Mn}$ and $\mathrm{Zn}$ in various proportions (Fig. 8a). The content of Mn varies from 0 to more than $60 \mathrm{wt} \%$. In particles with Mn content higher than $20 \mathrm{wt} \%$, Mn usually predominates over Fe. One particle with $66.1 \mathrm{wt} \%$ of $\mathrm{Mn}$ is devoid of Fe, but contains $\sim 2$ wt $\%$ of $\mathrm{Zn}$ (Fig. 8b). In several particles, high content of $\mathrm{Zn}$ was measured ( $\geq 20 \mathrm{wt} \%)$. $\mathrm{Cr}$ often co-occurs in Fe-rich particles containing $\mathrm{Mn}$ or $\mathrm{Zn}$ (Fig. 8c). Usually, the content of $\mathrm{Cr}$ is relatively low, but sporadically it is higher (e.g. $>25 \mathrm{wt} \%$ ) and dominates over $\mathrm{Fe}$. $\mathrm{Cu}$ co-occurs with other metals in 


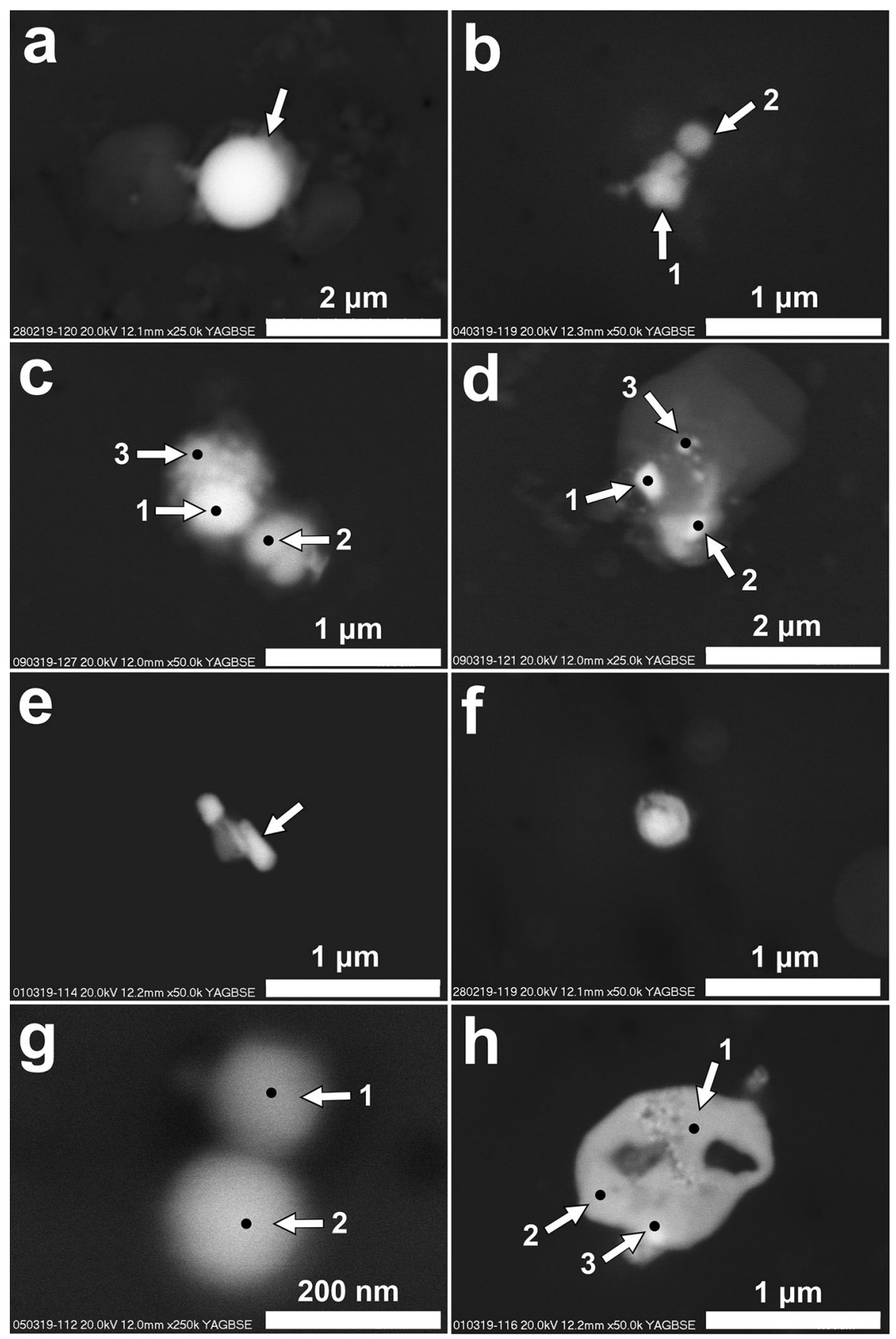

Fe-rich particles, but it is also noted as only one admixture in Fe-rich particles. In several particles, $\mathrm{Cu}$ was found as only one metal and its content was above $85 \mathrm{wt} \%$ (Fig. 8d). Ni occurs rarely, usually in Fe-rich particles containing $\mathrm{Mn}, \mathrm{Zn}$ and $\mathrm{Cr}$. Particles rich in $\mathrm{Pb}$ (> $60 \mathrm{wt} \%$ ) and $\mathrm{O}$ (with low content of $\mathrm{Fe}$ and $\mathrm{S}$ ) were noted (Fig. 8e), as well as particles containing $\mathrm{Sn}(>50$ wt $\%), \mathrm{Pb}(>11 \mathrm{wt} \%)$ and $\mathrm{O}(>35 \mathrm{wt} \%$ ) (Fig. 8f). Low content of Sn was determined in Fe-rich particles also containing $\mathrm{Mn}, \mathrm{Zn}$ and $\mathrm{Cr}$. Low content of $\mathrm{Sb}$ (slightly above $1.5 \mathrm{wt} \%$ ) was noted in Fe-rich particles containing low content of $\mathrm{Cu}$. In several Fe-rich 
४Fig. 8 Metal-rich particles (SEM, backscattered electrons images; content of major components presented for selected analytical spots). a. Spherical Fe-rich particle (arrow) (Fe$52.5 \mathrm{wt} \%$; Mn-23.1wt\%; Zn-1.2wt\%; O-17.3wt\%); b. Particles rich in $\mathrm{Mn}$ (particle 1: $\mathrm{Mn}-61.1 \mathrm{wt} \% ; \mathrm{Zn}-2.9 \mathrm{wt} \% ; \mathrm{Fe}-$ $8,4 \mathrm{wt} \% ; \mathrm{O}-21.7 \mathrm{wt} \% ; \mathrm{Si}-5.99 \mathrm{wt} \%$; particle 2: $\mathrm{Mn}-$ $66.1 \mathrm{wt} \% ; \mathrm{Zn}-2.1 \mathrm{wt} \% ; \mathrm{O}-22.4 \mathrm{wt} \% ; \mathrm{Si}-9.5 \mathrm{wt} \%)$; c. Particles rich in metals (spot 1: $\mathrm{Fe}-32.5 \mathrm{wt} \% ; \mathrm{Mn}-5.0 \mathrm{wt} \% ; \mathrm{Zn}-$ $20.3 \mathrm{wt} \% ; \mathrm{Cr}-4.1 \mathrm{wt} \% ; \mathrm{Ni}-1.8 \mathrm{wt} \% ; \mathrm{Mg}-9.6 \mathrm{wt} \% \mathrm{O}-$ 18.0wt\%; spot 2: Fe-34.7wt\%; Mn-4.3wt\%; Zn -21.5wt\%; $\mathrm{Cr}-2.7 \mathrm{wt} \%$; Ni-1.4wt\%; Mg-7.8wt\%; O-18.8wt\%; spot 3: $\mathrm{Fe}-22.7 \mathrm{wt} \% ; \mathrm{Mn}-4.0 \mathrm{wt} \% ; \mathrm{Zn}-9.2 \mathrm{wt} \% ; \mathrm{Cr}-25.9 \mathrm{wt} \%$; $\mathrm{Ni}-1.2 \mathrm{wt} \% ; \mathrm{Mg}-8.2 \mathrm{wt} \% ; \mathrm{O}-21.3 \mathrm{wt} \%)$; d. Cu-rich particles on aluminosilicate grain (spot 1: $\mathrm{Cu}-87.0 w t \%$; $-10.2 \mathrm{wt} \%$; spot 2: Cu 94.4wt\%; O-3.9wt\%; spot 3: $\mathrm{Cu}-86.6 \mathrm{wt} \%$; $\mathrm{O}-$ $11.7 \mathrm{wt} \%)$; e. Particle rich in $\mathrm{Pb}(\mathrm{Pb}-60.1 \mathrm{wt} \%$; $\mathrm{O}-28.2 \mathrm{wt} \%$; $\mathrm{Fe}-2.7 \mathrm{wt} \%$; $\mathrm{S}-9.0 \mathrm{wt} \%)$; f. Particle rich in $\mathrm{Sn}$ and $\mathrm{Pb}(\mathrm{Sn}-$ $53.7 \mathrm{wt} \% ; \mathrm{Pb}-11.2 \mathrm{wt} \%$; O-35.1wt\%); g. Small spherical Ferich particles (spot 1: $\mathrm{Fe}-65.7 ; \mathrm{Mn}-6.33 \mathrm{wt} \% ; \mathrm{Zn}-3.5 \mathrm{wt} \%$; $\mathrm{Cr}-1.1 \mathrm{wt} \% ; \mathrm{O}-22.5 \mathrm{wt} \%$; spot 2: $\mathrm{Fe}-74.9 \mathrm{wt} \%$; $\mathrm{Mn}-$ $2.8 \mathrm{wt} \%$; $\mathrm{O}-20.7 \mathrm{wt} \%$ ); h. Particle rich in $\mathrm{Pb}, \mathrm{Cl}$ and $\mathrm{O}$ (spot 1: $\mathrm{Pb}-52.6 \mathrm{wt} \% ; \mathrm{O}-18.6 \mathrm{wt} \% ; \mathrm{Cl}-26.8 \mathrm{wt} \% ;$ spot 2 : 52.6wt\%; O-20.1wt\%; Cl-24.7wt\%; spot 3; Pb-49.3wt\%; $\mathrm{O}-19.0 \mathrm{wt} \% ; \mathrm{Cl}-12.1 \mathrm{wt} \% ; \mathrm{S}-8.9 \mathrm{wt} \% ; \mathrm{K}-9.7 \mathrm{wt} \%)$

particles, $\mathrm{Ba}$ was noted. In numerous particles, $\mathrm{Si}, \mathrm{Al}$, $\mathrm{Ca}, \mathrm{Mg}, \mathrm{Na}, \mathrm{S}, \mathrm{Cl}$ and $\mathrm{K}$ were noted. Particles with very high content of $\mathrm{Fe}$ (ca. $90 \mathrm{wt} \%$ or higher) or $\mathrm{Cu}$ ( $>90 \mathrm{wt} \%$ ) are characterized by very low content of $\mathrm{O}$. It is possible to consider them as slightly oxidized metallic particles.

Fe-rich particles (oxides) commonly occur as irregular forms varying in size from several micrometers to tens of nanometers. Spherical Fe-rich particles are less common than irregular ones. The size of spherical Fe-rich particles varies from several micrometers to below $100 \mathrm{~nm}$ (Fig. 8g). Small spherical Fe-rich particles (ca. $100 \mathrm{~nm}$ ) often occur in clusters containing several particles slightly differing in size (above and below $100 \mathrm{~nm}$ ). The occurrence of Fe-rich spherical particles around or below $100 \mathrm{~nm}$ in diameter, according to our knowledge, has not been noted in atmospheric PM in Krakow. The study by Moteki et al. (2017) indicated the presence of aggregates of numerous anthropogenic $\mathrm{FeOx}$ monomers with sizes ranging from several to $100 \mathrm{~nm}$ in aerosol from the East Asia. Similar aggregates of spherical $\mathrm{Fe}$ oxides were described from the atmosphere of megacities (e.g., Tokyo; Adachi et al. 2016). According to Sanderson et al. (2016), Fe nanoparticles occurring in the atmosphere of urban environments can be related to road traffic (formed in engine cylinders or braking systems). Liati et al. (2015) found that road traffic metal nanoparticles are derived mainly from metal fragments melting in diesel engines. Xing et al. (2019) noticed $\mathrm{Fe}$ nanoparticles in material emitted from gasoline direct-injection engines. The origin of particles of this type from metallurgical industrial sources is probable (Jenkins 2003). The small spherical Fe-rich particles are similar to the airborne particles detected in the human brain by Maher et al. (2016). The health impact of Fe-bearing nanoparticles in urban environments was discussed by Gonet and Maher (2019).

Low $\mathrm{S}$ content was noted in numerous particles, but higher concentrations corresponding to values typical for sulfates were rarely noted. Ca sulfates (sometimes containing low amounts of $\mathrm{Cl}, \mathrm{Na}, \mathrm{K}, \mathrm{Si}, \mathrm{Al}$ ) were noted. The complex chemical composition indicates the internally mixed state of these particles. Ba sulfate (barite) particles were also found. Single particles of $\mathrm{Fe}$ - or Zn-rich sulfates were also noted.

Cl-rich particles containing metals were rarely determined. All of them were characterized by high $\mathrm{Pb}$ content (ca. $50 \mathrm{wt} \%$ ). The content of $\mathrm{O}$ indicates that the particles are not simple chlorides (Fig. 8h). The presence of $\mathrm{S}$ noted in one particle, and $\mathrm{K}, \mathrm{Si}$ and $\mathrm{Al}$ in others, suggests their chemical complexity.

Determination of the carbonates in aerosols using the SEM-EDS method and carbon-coated samples is doubtful. Particles rich in $\mathrm{Ca}$ and $\mathrm{Mg}$ characterized by very low content of $\mathrm{Si}$ and $\mathrm{Al}$ were considered to be carbonates. The content of transition metals in these particles is low (e.g., Fe rarely above $3 \mathrm{wt} \%$; Mn up to $1 \mathrm{wt} \%)$.

Relatively numerous particles containing transition metals and relatively rich in $\mathrm{Si}$ and $\mathrm{Al}$ were arbitrary included into the group of aluminosilicates. The content of $\mathrm{Fe}$ varies from 2 to $39 \mathrm{wt} \%$. In some particles, $\mathrm{Mn}$ is present $(0.5-32.9 \mathrm{wt} \%)$, along with $\mathrm{Zn}$ (1-2 wt \%), Ti (0.3-20.6 wt \%) and Ba (ca. $1 \mathrm{wt} \%)$. The aluminosilicates often contain low amounts of $\mathrm{K}, \mathrm{Ca}$, $\mathrm{Mg}, \mathrm{P}, \mathrm{S}$ and $\mathrm{Cl}$. The majority of the aluminosilicate particles are irregular, with spherical ones occurring less often. These spherical particles are usually below $2.5 \mu \mathrm{m}$ in size, while some are around $100 \mathrm{~nm}$.

There is only a scarce occurrence of particles $(<2.5 \mu \mathrm{m}$ in size ) composed of $\mathrm{Zr}(32-62 \mathrm{wt} \%)$, Ce (8-16 wt\%), $\mathrm{O}$ and $\mathrm{Al}$, likely originating from catalyst material used in diesel engine vehicles (Davies et al. 2018). 
Single-particle analysis of various types of metalbearing airborne particles in the studied samples cannot be considered as an indicator of the concentration of metals in aerosols or as a measure of their size segregation. Variation in the forms of occurrence of metals in aerosol particles, as well as in the size of particles, indicates the variability of their properties, but determination of these properties (e.g., chemical speciation, oxidation state, solubility and bioavailability) requires more advanced studies. Generally, the bioavailability of metals increases with decreasing PM size (Chapman et al. 1997).

The abundance of particles containing transition metals (with high content of metal oxides) in the studied samples indicates their potential for adverse health impacts through oxidative stress (Biswas and Wu 2005; Gonet and Maher 2019; Kelly 2003; Manke et al. 2013; Sørensen et al. 2005). Oxidative stress is formed according to Fenton and Haber-Weiss reactions (Biswas and Wu 2005; Kanti Das et al. 2015). Fe nanoparticles are important in the development of oxidative stress (Biswas and $\mathrm{Wu} 2005$; Gonet and Maher 2019). The redox activity of metals in PM depends not only on the content of metals, but also on the bioavailability, and the content of other components such as sulfates (Nawrot et al. 2009). Gaseous organic compounds can increase metal solubility via metal-organic complexation (Okochi and Brimblecombe 2002).

\section{Microbiological analysis}

Twelve different species of bacteria were isolated from the collected aerosol samples. The most frequently isolated species was Gram-positive sporulating Bacillus licheniformis (isolated four times). This was a similar result to the one obtained by Bragoszewska and Pastuszka (2018), who also found that the most prevalent bacteria in outdoor air in Gliwice were Gram-positive rods forming endospores, while Bacillus cereus was the most commonly isolated bacterium, and $B$. licheniformis was not found. In our study, seven other Bacillus species were identified in various samples, while in the aforementioned study by Brągoszewska and Pastuszka (2018), only four different species were found. Contrary to another study by Brągoszewska et al. (2020), concerning indoor and outdoor microbiological air quality in a high school gym in Southern Poland, we did not isolate
Corynebacterium. The reasons for such results are probably the differences in air sampling and the identification method. Brągoszewska et al. (2020) used an Andersen six-stage impactor ANDI for sampling, but in case of identification, the MALDITOF method was used in our study, while biochemical API tests were utilized in the cited studies. Among the staphylococci isolated from the aerosol samples collected from air, there were two different species: Staphylococcus warneri and Staphylococcus epidermidis. Among the streptococci isolates, there were Streptococcus salivarius, Streptococcus parasanguinis, Streptococcus vestibularis and Streptococcus sanguinis. Although there was no medium dedicated to finding fungi, some colonies of to these organisms were demonstrated through the use of blood agar. Identification tests were also performed in this case. The isolated mold fungi belonged to the genus Aspergillus. In most cases, microbial growth was obtained both by direct culture on agar and after preincubation on tryptic soy broth. Only in two samples, where the culture on agar was negative, bacterial growth was obtained after pre-incubation in the broth. In quantitative cultures, the total number from $2 *$ $10^{2} \mathrm{CFU} / \mathrm{ml}$ to $5 * 10^{8} \mathrm{CFU} / \mathrm{ml}$ of bacteria was found. Detailed results of the microbiological testing are presented in Table 3.

The most common bacteria found during the study that can cause infections in humans are B.cereus, Stenotrophomonas maltophilia, S. warneri and $S$. epidermidis.

Bacillus cereus is an opportunistic pathogen causing primarily food intoxication but also other infectious diseases. Besides soil, which is its primary reservoir, it can be isolated from vegetation and water and can colonize mammals. From the environment, Bacillus spores can be transferred into various raw materials used in the food industry. The host can be contaminated by spores or vegetative cells present in food, inhaled air, or enter the body through a wound (Ehling-Schulz et al. 2019, Ramarao et al. 2020). Stenotrophomonas maltophilia is a commensal and a pathogen that is more and more often isolated from people with normal immunity. This bacterium is also more and more frequently resistant to antibiotics. It is involved in skin and soft tissue infections, bloodstream infections, endocarditis, meningitis, acute respiratory infection and others. S. maltophilia is an environmental bacterium found in water and as part of 
Table 3 Results of microbiological analysis of aerosol samples

\begin{tabular}{|c|c|c|c|c|c|}
\hline $\begin{array}{l}\text { Date } \\
(\mathrm{dd} / \mathrm{mm} / \\
\text { ууyy })\end{array}$ & $\begin{array}{l}\text { Microorganism morphology } \\
\text { (result of Gram stained) }\end{array}$ & $\begin{array}{l}\text { Species } \\
\text { (qualitative culture) }\end{array}$ & $\begin{array}{l}\text { Species (quantitative } \\
\text { culture) }\end{array}$ & $\begin{array}{l}\mathrm{CFU} / \mathrm{ml} \\
\text { tryptic soy } \\
\text { agar }\end{array}$ & $\begin{array}{l}\text { CFU/ml } \\
\text { Columbia } \\
\text { agar }\end{array}$ \\
\hline \multirow[t]{6}{*}{ 28/02/2019 } & $\begin{array}{l}\text { Gram-positive sporulating } \\
\text { bacilli }\end{array}$ & Bacillus licheniformis & Bacillus licheniformis & $6 \times 10^{7}$ & $4 \times 10^{7}$ \\
\hline & $\begin{array}{l}\text { Gram-positive sporulating } \\
\text { bacilli }\end{array}$ & $\begin{array}{r}\text { Paenibacillus } \\
\text { barengoltzii }\end{array}$ & $\begin{array}{r}\text { Paenibacillus } \\
\text { barengoltzii }\end{array}$ & $1.6 \times 10^{6}$ & $1.1 \times 10^{8}$ \\
\hline & Gram-positive cocci & Staphylococcus warneri & Staphylococcus warneri & - & $6 \times 10^{6}$ \\
\hline & Gram-positive cocci & Rothia terrae & - & - & - \\
\hline & Gram-positive cocci & Micrococcus luteus & - & - & - \\
\hline & Molds & - & Aspergillus sp. & single & - \\
\hline \multirow[t]{4}{*}{$1 / 03 / 2019$} & $\begin{array}{l}\text { Gram-positive sporulating } \\
\text { bacilli }\end{array}$ & Bacillus licheniformis & Bacillus licheniformis & $3 \times 10^{8}$ & $1 \times 10^{8}$ \\
\hline & $\begin{array}{l}\text { Gram-positive sporulating } \\
\text { bacilli }\end{array}$ & Bacillus pumilus & Bacillus pumilus & $1.6 \times 10^{6}$ & $3 \times 10^{6}$ \\
\hline & Gram-positive cocci & $\begin{array}{l}\text { Staphylococcus } \\
\text { epidermidis }\end{array}$ & - & - & - \\
\hline & $\begin{array}{l}\text { Gram-positive sporulating } \\
\text { bacilli }\end{array}$ & - & Bacillus altitudinis & $4 \times 10^{7}$ & - \\
\hline \multirow[t]{5}{*}{ 4/03/2019 } & $\begin{array}{l}\text { Gram-positive sporulating } \\
\text { bacilli }\end{array}$ & Bacillus simplex & Bacillus simplex & $2 \times 10^{6}$ & $1 \times 10^{6}$ \\
\hline & $\begin{array}{l}\text { Gram-positive sporulating } \\
\text { bacilli }\end{array}$ & Bacillus clausii & Bacillus clausii & $3 \times 10^{6}$ & - \\
\hline & Gram-positive cocci & Streptococcus salivarius & Streptococcus salivarius & - & $9 \times 10^{5}$ \\
\hline & Gram-positive cocci & $\begin{array}{l}\text { Streptococcus } \\
\text { parasanguinis }\end{array}$ & $\begin{array}{l}\text { Streptococcus } \\
\text { parasanguinis }\end{array}$ & - & $2 \times 10^{5}$ \\
\hline & $\begin{array}{l}\text { Gram-positive sporulating } \\
\text { bacilli }\end{array}$ & - & $\begin{array}{l}\text { Brevibacillus } \\
\text { borstelensis }\end{array}$ & $3 \times 10^{6}$ & - \\
\hline \multirow[t]{2}{*}{$5 / 03 / 2019$} & $\begin{array}{l}\text { Gram-positive sporulating } \\
\text { bacilli }\end{array}$ & Bacillus licheniformis & Bacillus licheniformis & $5 \times 10^{8}$ & $1 \times 10^{8}$ \\
\hline & Gram-positive cocci & $\begin{array}{l}\text { Streptococcus } \\
\text { vestibularis }\end{array}$ & $\begin{array}{l}\text { Streptococcus } \\
\text { vestibularis }\end{array}$ & - & $1.6 \times 10^{7}$ \\
\hline \multirow[t]{4}{*}{ 9/03/2019 } & $\begin{array}{l}\text { Gram-positive sporulating } \\
\text { bacilli }\end{array}$ & $\begin{array}{l}\text { Bacillus } \\
\quad \text { amyloliquefaciens }\end{array}$ & $\begin{array}{l}\text { Bacillus } \\
\quad \text { amyloliquefaciens }\end{array}$ & $4 \times 10^{8}$ & $1 \times 10^{7}$ \\
\hline & $\begin{array}{l}\text { Gram-positive sporulating } \\
\text { bacilli }\end{array}$ & Bacillus cereus & Bacillus cereus & $2 \times 10^{7}$ & $3 \times 10^{8}$ \\
\hline & $\begin{array}{l}\text { Gram-positive sporulating } \\
\text { bacilli }\end{array}$ & Bacillus pumilus & Bacillus pumilus & $1.3 \times 10^{6}$ & $2 \times 10^{6}$ \\
\hline & Gram-positive cocci & Streptococcus sanguinis & - & - & - \\
\hline \multirow[t]{4}{*}{ 10/03/2019 } & $\begin{array}{l}\text { Gram-positive non-sporulating } \\
\text { bacilli }\end{array}$ & Lactobacillus kefiri & Lactobacillus kefiri & $5 \times 10^{2}$ & $3 \times 10^{1}$ \\
\hline & $\begin{array}{l}\text { Gram-positive sporulating } \\
\text { bacilli }\end{array}$ & Bacillus subtilis & Bacillus subtilis & $2 \times 10^{2}$ & $1.5 \times 10^{2}$ \\
\hline & Gram-negative rods & Pantoea agglomerams & - & - & - \\
\hline & Molds & Aspergillus niger & - & - & - \\
\hline \multirow[t]{2}{*}{$11 / 03 / 2019$} & $\begin{array}{l}\text { Gram-positive sporulating } \\
\text { bacilli }\end{array}$ & Bacillus cereus & Bacillus cereus & $1.7 \times 10^{8}$ & $2 \times 10^{8}$ \\
\hline & $\begin{array}{l}\text { Gram-positive sporulating } \\
\text { bacilli }\end{array}$ & Bacillus altitudinis & Bacillus altitudinis & $1 \times 10^{7}$ & $4.2 \times 10^{7}$ \\
\hline
\end{tabular}


Table 3 continued

\begin{tabular}{|c|c|c|c|c|c|}
\hline $\begin{array}{l}\text { Date } \\
\text { (dd/mm/ } \\
\text { уууy) }\end{array}$ & $\begin{array}{l}\text { Microorganism morphology } \\
\text { (result of Gram stained) }\end{array}$ & $\begin{array}{l}\text { Species } \\
\text { (qualitative culture) }\end{array}$ & $\begin{array}{l}\text { Species (quantitative } \\
\text { culture) }\end{array}$ & $\begin{array}{l}\mathrm{CFU} / \mathrm{ml} \\
\text { tryptic soy } \\
\text { agar }\end{array}$ & $\begin{array}{l}\text { CFU/ml } \\
\text { Columbia } \\
\text { agar }\end{array}$ \\
\hline & Molds & Aspergillus fumigatus & - & - & - \\
\hline & Gram-positive cocci & Staphylococcus warneri & Staphylococcus warneri & - & $1 \times 10^{6}$ \\
\hline & $\begin{array}{l}\text { Gram-positive non-sporulating } \\
\text { bacilli }\end{array}$ & Lactobacillus plantarum & - & - & - \\
\hline & Gram dodatni ziarenkowiec & Micrococcus luteus & - & - & - \\
\hline & Gram-negative rods & $\begin{array}{l}\text { Stenotrophomonas } \\
\text { maltophilia }\end{array}$ & - & - & - \\
\hline \multirow[t]{4}{*}{ 13/03/2019 } & $\begin{array}{l}\text { Gram-positive sporulating } \\
\text { bacilli }\end{array}$ & Bacillus altitudinis & Bacillus altitudinis & $1.4 \times 10^{7}$ & $9 \times 10^{6}$ \\
\hline & $\begin{array}{l}\text { Gram-positive sporulating } \\
\text { bacilli }\end{array}$ & Bacillus licheniformis & Bacillus licheniformis & $8 \times 10^{7}$ & $1 \times 10^{7}$ \\
\hline & $\begin{array}{l}\text { Gram-positive non-sporulating } \\
\text { bacilli }\end{array}$ & Lactobacillus plantarum & - & - & - \\
\hline & Gram-positive cocci & Micrococcus luteus & - & - & - \\
\hline
\end{tabular}

the microflora of animals. The route of transmission is the contact route through both healthy and injured skin and mucous membranes (Adegoke et al. 2017). S.warneri and S. epidermidis are coagulase-negative staphylococci, which are part of the physiological microbiota of the skin and mucous membranes. They are also important pathogens, especially in hospitals, because it is more common for them to infect immunocompromised patients. The main route of transmission for Staphylococcus bacteria is the contact route, but indoor air testing indicates the presence and the possibility of long-term survival of numerous bacteria of this genus in the air (Becker et al. 2014; Lee et al. 2019; Lenart-Boroń et al. 2017).

In patients with severely compromised immune systems, any organism may be potentially pathogenic. Aspergillus species are also dangerous pathogens, primarily for people with specific predisposing factors. Tham et al. (2017) found that exposure to the spores of several outdoor fungal taxa, including Alternaria, Leptosphaeria, Coprinus and Drechslera species, was associated with the risk of asthma exacerbations in children and adolescents, regardless of their sensitization to Alternaria and Cladosporium species. In our study, these species were not found. Our results concerning the fungal composition of bioaerosols are contrary to the results of Bugajny et al. (2005), where in the outdoor air in Poznan, they found higher concentrations of fungi than bacteria, and with more diverse composition (Cladosporium spp., Mucor spp. and Alternaria spp.). The difference probably results from the fact of choosing a medium dedicated to bacterial culture in our study.

The results of microbiological analysis should be treated as preliminary ones, due to limitations in sampling as well as the selected method of microorganism identification. Our method for microbiological tests did not allow to identify the viable but not culturable bacteria and a broad diversity of fungi or viruses. According to Ravva et al. (2012) and Fahlgren et al. (2010), culturable bacteria represent only 1 to $20 \%$ of total bacterial diversity; therefore, the method used limited our ability to study the ecology of entire bacterial communities. More recently, increasing accessibility to high-throughput next-generation sequencing (NGS) technologies has enabled identification of hundreds of species and their antimicrobial resistant genes in single metagenomic samples. Metagenomic high-throughput sequencing is currently being explored for expanded use in public health surveillance (Otto, 2017). We believe that our research is only a small introduction and should be continued at the level of both classical and molecular methods.

Additionally, the study was conducted over eight different days during one season of the year, and the diversity of microorganisms between individual days was relatively large. More samples taken in different weather conditions and with several repetitions should 
thus be taken and subjected to microbiological testing to obtain complex data of microbiological air contamination (and potential health risk), and allow statistical analysis.

More advanced methods of sampling (e.g., Kim et al. 2017), analyses (e.g., Albrecht et al. 2007; Bowers et al. 2009; Gohli et al. 2019) as well as sampling strategy are needed to obtain precise information about the composition of microorganism assemblage and their variations.

\section{Conclusions}

1. The domination of submicron particles in the air pollution in Krakow (and the high concentration of ultrafine particles) indicates that the exposure to ambient air has a very important health impact.

2. Particles originating from fuel combustion dominate in the studied aerosol samples, taking into account the number of particles.

3. Tar balls are relatively common in the studied samples. Their size and composition (aromatic compounds) indicate a potential health impact.

4. Soot occurring in various forms (small or large agglomerates, lacey or compact) is very common in the studied samples. The health impact of soot is strong because of the small particle size, as well as the content of organic compounds and metals.

5. Numerous types of metal-containing particles were identified, differing in the content of the main and accompanying metals and in the chemical form of occurrence. The abundance of transition metals occurring commonly in the form of oxides suggests that these particles could exert a strong and adverse health impact because of strong oxidative stress.

6. The aerosol particles collected in February and March 2019 in Krakow can be considered to indicate an important threat to human health because of the very high content of submicron and ultrafine particles (nanoparticles), the high content of hazardous fuel combustion-related particles (soot and tar ball-type particles) and the abundance of particles rich in transition metals. The detailed characteristics of the particles indicate that the threat is severe, despite the lowering of the mass concentration of PM.
7. The results of this study of bacterial air contamination are generally similar to those of other researchers in Poland conducted with the usage of conventional diagnostics based on culture. Among the isolated and identified bacteria and fungi, some species may cause an infection in vulnerable, immunocompromised patients. The number of isolated species in this study is probably limited due to the method applied.

8. The results of microbiological analysis, which should be treated as preliminary ones, indicate variation in terms of both qualitative and quantitative results. Because of limited number of analyzed samples, it is difficult to interpret this variation.

Acknowledgments Authors are grateful to Waldemar Obcowski for his help in preparation of figures.

Authors' contributions All authors have made substantial contributions to the conception and design, acquisition of data, or analysis and interpretation of data; drafting the article or revising it critically for important intellectual content; and final approval of the version to be submitted for publication.

Funding This research was funded by the Ministry of Science and Higher Education through the statutory tasks of the Faculty of Geography and Biology, Pedagogical University of Krakow (Wanda Wilczyńska-Michalik), and Faculty of Geography and Geology, Jagiellonian University (Marek Michalik). Other authors did not receive support from any organization for the submitted work.

Availability of data and material (data transparency): Detailed analytical data are stored by the authors and are available on request.

Code availability (software application or custom code): Not applicable.

\section{Declarations}

Conflicts of interest The authors have no relevant financial or non-financial interests to disclose.

Ethics approval This research did not involve human participants or animals.

Consent to participate This research did not involve human subjects.

Consent for publication Not applicable.

Open Access This article is licensed under a Creative Commons Attribution 4.0 International License, which permits use, 
sharing, adaptation, distribution and reproduction in any medium or format, as long as you give appropriate credit to the original author(s) and the source, provide a link to the Creative Commons licence, and indicate if changes were made. The images or other third party material in this article are included in the article's Creative Commons licence, unless indicated otherwise in a credit line to the material. If material is not included in the article's Creative Commons licence and your intended use is not permitted by statutory regulation or exceeds the permitted use, you will need to obtain permission directly from the copyright holder. To view a copy of this licence, visit http://creativecommons.org/licenses/by/4.0/.

\section{References}

Adachi, K., Moteki, N., Kondo, Y., \& Igarashi, Y. (2016). Mixing states of light-absorbing particles measured using a transmission electron microscope and a single-particle soot photometer in Tokyo, Japan. Journal of Geophysical Research: Atmosphere, 121, 9153-9164. https://doi.org/ 10.1002/2016JD025153

Adachi, K., Sedlacek, A. J., III., Kleinman, L., Springston, S. R., Wang, J., Chand, D., Hubbe, J. M., Shilling, J. E., Onasch, T. B., Kinase, T., Sakata, K., Takahashi, Y., \& Buseck, P. R. (2019). Spherical tarball particles form through rapid chemical and physical changes of organic matter in biomass-burning smoke. PNAS, 116, 39. https://doi.org/10. 1073/pnas. 1900129116

Adachi, K., \& Buseck, P. R. (2011). Atmospheric tar balls from biomass burning in Mexico. Journal of Geophysical Research, 116, D05204. https://doi.org/10.1029/ 2010JD015102

Adegoke, A. A., Stenström, T. A., \& Okoh, A. I. (2017). Stenotrophomonas maltophilia as an Emerging Ubiquitous Pathogen: Looking Beyond Contemporary Antibiotic Therapy. Frontiers in Microbiology, 8, 2276. https://doi. org/10.3389/fmicb.2017.02276

Air quality in Europe (2019) report. EEA Report, No 10/2019, 1-104. European Environment Agency.

Albrecht, A., Witzenberger, R., Bernzen, U., \& Jackel, U. (2007). Detection of airborne microbes in a composting facility by cultivation based and cultivation-independent methods. Annals of Agricultural and Environmental Medicine, 14, 81-85

Atiku, F. A., Mitchell, E. J. S., Lea-Langton, A. R., Jones, J. M., Williams, A., \& Bartle, K. D. (2016). The impact of fuel Properties on the composition of soot produced by the combustion of residential solid fuels in domestic stove. Fuel Processing Technology, 151, 117-125. https://doi. org/10.1016/j.fuproc.2016.05.032

Ayres, J. G., Borm, P., Cassee, F. R., Castranova, V., Donaldson, K., Ghio, A., Harrison, R. M., Hider, R., Kelly, F., \& Kooter, I. M. (2008). Evaluating the toxicity of airborne particulate matter and nanoparticles by measuring oxidative stress potential-A workshop report and consensus statement. Inhalation Toxicology, 20, 75-99. https://doi. org/10.1080/08958370701665517

Bakand, S., Hayes, A., \& Dechsakulthorn, F. (2012). Nanoparticles: A review of particle toxicology following inhalation exposure. Inhalation Toxicology, 24, 125-135. https://doi.org/10.3109/08958378.2010.642021

Becker, K., Heilmann, C., \& Peters, G. (2014). Coagulasenegative staphylococci. Clinical Microbiology Reviews, 27, 870-926. https://doi.org/10.1128/CMR.00109-13

Biswas, P., \& Wu, C.-Y. (2005). Nanoparticles and the Environment. Journal of the Air and Waste Management Association, 55, 708-746

Bogacki, M., Oleniacz, R., Mazur, M., \& Dziugieł, M. (2010). Number and size measurements of aerosol particles in urban air using the optical/electronic method. In J. Konieczyński (Ed.), Ochrona powietrza w teorii i praktyce (pp. 15-22, vol. 2), Zabrze: IPIŚ PAN.

Bovallius, Å., Bucht, B., Roffey, R., \& Ånäs, P. (1978). Threeyear investigation of the natural airborne bacterial flora at four localities in Sweden. Applied and Environmental Microbiology, 35, 847-852

Bové, H., Bongaerts, E., Slenders, E., Bijnens, E. M., Saenen, N. D., Gyselaers, W., Van Eyken, P., Plusquin, M., Roeffaers, M. B. J., Ameloot, M., \& Nawrot, T. S. (2019). Ambient black carbon particles reach the fetal side of human placenta. Nature Communications, 10, 3866. https://doi.org/ 10.1038/s41467-019-11654-3

Bowers, R. M., Lauber, C. L., Wiedinmyer, C., Hamady, M., Hallar, A., Fall, R., Knight, R., \& Fierer, N. (2009). Characterization of airborne microbial communities at a high-elevation site and their potential to act as atmospheric ice nuclei. Applied and Environmental Microbiology, 75, 5121-5130. https://doi.org/10.1128/AEM.00447-09

Brągoszewska, E., \& Pastuszka, J. S. (2018). Influence of meteorological factors on the level and characteristics of culturable bacteria in the air in Gliwice, Upper Silesia (Poland). Aerobiologia, 34, 241-255. https://doi.org/10. 1007/s10453-018-9510-1

Brągoszewska, E., Biedroń, I., \& Mainka, A. (2020). Microbiological air quality in a highschool gym located in an urban area of Southern Poland-Preliminary Research. Atmosphere, 11, 797. https://doi.org/10.3390/atmos11080797

Bugajny, A., Knopkiewicz, M., Piotraszewska-Pająk, A., Sekulska-Stryjakowska, M., Stach, A., \& Filipiak, M. (2005). On the microbiological quality of the outdoor air in Poznań, Poland. Polish Journal of Environmental Studies, 14, 287-293

Burkowska-But, A., Kalwasińska, A., \& Swiontek-Brzezińska, M. (2014). The role of open-air inhalatoria un the air quality improvement in SPA towns. International Journal of Occupational Medicine and Environmental Health, 27, 560-570. https://doi.org/10.2478/s13382-014-0274-8

Burrows, S. M., Elbert, W., Lawrence, M. G., \& Poschl, U. (2009). Bacteria in the global atmosphere-Part 1: Review and synthesis of literature data for different ecosystems. Atmospheric Chemistry and Physics, 9, 9263-9280

Buseck, P. R., \& Adachi, K. (2008). Nanoparticles in the atmosphere. Elements, 4, 389-394

Buseck, P. R., Adachi, K., Gelencsér, A., Tompa, É., \& Pósfai, M. (2012). Are black carbon and soot the same? Atmospheric Chemistry and Physics Discussions, 12, 24821-24846. https://doi.org/10.5194/acpd-12-248212012

Cakmak, S., Dales, R., Kauri, L. M., Mahmud, M., Van Ryswyk, K., Vanos, J., Liu, L., Kumarathasan, P., Thomson, E., 
Vincent, R., \& Weichenthal, S. (2014). Metal composition of fine particulate air pollution and acute changes in cardiorespiratory physiology. Environmental Pollution, 189, 208-214. https://doi.org/10.1016/j.envpol.2014.03.004

Chapman, R. S., Watkinson, W. P., Dreher, K. L., \& Costa, D. L. (1997). Ambient particulate matter and respiratory and cardiovascular illness in adults: Particle-borne transition metals and the heart-lung axis. Environmental Toxicology and Pharmacology, 4, 331-338

China, S., Mazzoleni, C., Gorkowski, K., Aiken, A. C., \& Dubey, M. K. (2013). Morphology and mixing state of individual freshly emitted wildfire carbonaceous particles. Nature Communications, 4, 2122. https://doi.org/10.1038/ ncomms 3122

Davies, C., Thompson, K., Cooper, A., Golunski, S., Taylor, S. H., Macias, M. B., Doustdar, O., \& Tsolakis, A. (2018). Simultaneous removal of NOx and soot particulate from diesel exhaust by in-situ catalytic generation and utilisation of $\mathrm{N}_{2} \mathrm{O}$. Applied Catalysis B: Environmental, 239, 10-15. https://doi.org/10.1016/j.apcatb.2018.07.072

Deguillaume, L., Leriche, M., Amato, P., Ariya, P. A., Delort, A.-M., Pöschl, U., Chaumerliac, N., Bauer, H., Flossmann, A. I., \& Morris, C. E. (2008). Microbiology and atmospheric processes: chemical interactions of primary biological aerosols. Biogeosciences, 5, 1073-1084

Dellinger, B., Pryor, W. A., Cueto, R., Squadrito, G. L., \& Deutsch, W. A. (2000). The role of combustion-generated radicals in the toxicity of PM2.5. Proceedings of the Combustion Institute, 28, 2675-2681

Donaldson, K., \& Stone, V. (2003). Current hypotheses on the mechanisms of toxicity of ultrafine particles. Annali dell'Istituto Superiore di Sanità, 39, 405-410.

Dueker, M. E., O’Mullan, G. D., Martínez, J. M., Juhl, A. R., \& Weathers, K. C. (2017). Onshore wind speed modulates microbial aerosols along an Urban Waterfront. Atmosphere, 8, 215. https://doi.org/10.3390/atmos8110215

Ehling-Schulz, M., Lereclus, D., \& Koehler, T. M. (2019). The Bacillus cereus Group: Bacillus Species with Pathogenic Potential. Microbiology Spectrum, 7.https://doi.org/ 10.1128/microbiolspec.GPP3-0032-2018

Fahlgren, C., Hagström, A., Nilsson, D., \& Zweifel, U. L. (2010). Annual variations in the diversity, viability, and origin of airborne bacteria. Applied and Environmental Microbiology, 76, 3015-3025. https://doi.org/10.1128/ AEM.02092-09

Fang, Z., Ouyang, Z., Zheng, H., Wang, X., \& Hu, L. (2007). Culturable airborne bacteria in outdoor environments in Beijing, China. Microbial Ecology, 54, 487-496. https:// doi.org/10.1007/s00248-007-9216-3

Fortoul, T. I., Rodriguez-Lara, V., Gonzalez-Villalva, A., RojasLemus, M., Colin-Barenque, L., Bizarro-Nevares, P., García-Peláez, I., Ustarroz-Cano, M., López-Zepeda, S., Cervantes-Yépez, S., López-Valdez, N., Meléndez-García, N., Espinosa-Zurutuza, M., Cano-Gutierrez, G., \& CanoRodríguez, M. C. (2015). Health effects of metals in particulate matter. Current Air Quality Issues, Farhad Nejadkoorki, IntechOpen, . https://doi.org/10.5772/59749

Gohli, J., Oline Bøifot, K. O., Moen, L. V., Pastuszek, P., Skogan, G., Klas, I., Udekwu, K. I., \& Dybwad, M. (2019). The subway microbiome: Seasonal dynamics and direct comparison of air and surface bacterial communities.
Microbiome, 7, 160. https://doi.org/10.1186/s40168-0190772-9

Gonet, T., \& Maher, B. A. (2019). Airborne, vehicle-derived Febearing nanoparticles in the urban environment: A Review. Environmental Science and Technology, 53, 9970-9991. https://doi.org/10.1021/acs.est.9b01505

Hu, T., Cao, J., Shen, Z., Wang, G., Lee, S., \& Ho, K. (2012). Size Differentiation of individual atmospheric Aerosol during Winter in Xi'an, China. Aerosol and Air Quality Research, 12, 951-960. https://doi.org/10.4209/aaqr.2012. 01.0011

Jacobson, M. Z. (2012). Air pollution and global warming. Cambridge University Press.

Jenkins, N. T. (2003). Chemistry of Airborne Particles from Metallurgical Processing. Ph.D. Thesis. Massachusetts Institute of Technology.

Kanti Das, T., Wati, M. R., \& Fatima-Shad, K. (2015). Oxidative stress gated by Fenton and Haber Weiss reactions and its association with Alzheimer's disease. Archives of Neurosciences, 2(2), e60038. https://doi.org/10.5812/ archneurosci.20078

Kelly, F. J. (2003). Oxidative stress: its role in air pollution and adverse health effects. Occupational and Environmental Medicine, 60, 612-616

Kelly, F. J., \& Fussell, J. C. (2015). Air pollution and public health: emerging hazards and improved understanding of risk. Environmental Geochemistry and Health, 37, 631-649. https://doi.org/10.1007/s10653-015-9720-1

Keogh, D. U., Ferreira, L., \& Morawska, L. (2014). Development of a particle number and particle mass vehicle emissions inventory for an urban fleet. Environmental Modelling and Software, 24, 1323-1331. https://doi.org/ 10.1016/j.envsoft.2009.05.003

Kim K., Kabir E., \& Jahan S.A., (2017). Airborne bioaerosols and their impact on human health. Journal of Environmental Science, 2017. https://doi.org/10.1016/j.jes.2017. 08.027

Krzemińska-Flowers, M., Bem, H., \& Górecka, H. (2006). Trace metals concentration in size-fractioned urban air particulate matter in Łódź, Poland. I. Seasonal and site fluctuations. Polish Journal of Environmental Studies, 15, 759-767

Kumar, P., Robins, A., Vardoulakis, S., \& Britter, R. (2010). A review of the characteristics of nanoparticles in the urban atmosphere and the prospects for developing regulatory controls. Atmospheric Environment, 44, 5035-5052. https://doi.org/10.1016/j.atmosenv.2010.08.016

Kumar, P., Ketzel, M., Vardoulakis, S., Pirjola, L., \& Britter, R. (2011). Dynamics and dispersion modelling of nanoparticles from road traffic in the urban atmospheric environment-A review. Journal of Aerosol Science, 42, 580-603. https://doi.org/10.1016/j.jaerosci.2011.06.001

Kumar, P., Robins, A., Vardoulakis, S., \& Quincey, P. (2011). Technical challenges in tackling regulatory concerns for urban atmospheric nanoparticles. Particuology, 9, 566-571. https://doi.org/10.1016/j.partic.2011.06.002

Kura, B., Verma, S., Ajdari, E., \& Iyer, A. (2013). Growing public health concerns from poor urban air quality: Strategies for sustainable urban living. Computational Water, Energy, and Environmental Engineering, 2013, 1-9. https://doi.org/10.4236/cweee.2013.22B001 
Kuuluvainen, H., Rönkkö, T., Järvinen, A., Saari, S., Karjalainen, P., Lähde, T., Pirjola, L., Niemi, J. V., Hillamo, R., \& Keskinen, J. (2016). Lung deposited surface area size distributions of particulate matter in different urban areas. Atmospheric Environment, 136, 105-113. https://doi.org/ 10.1016/j.atmosenv.2016.04.019

Lelieveld, J., Evans, J. S., Fnais, M., Giannadaki, D., \& Pozzer, A. (2015). The contribution of outdoor air pollution sources to premature mortality on a global scale. Nature, 525, 367-371. https://doi.org/10.1038/nature15371

Lelieveld, J., Pozzer, A., Pöschl, U., Fnais, M., Haines, A., \& Münzel, T. (2020). Loss of life expectancy from air pollution compared to other risk factors: a worldwide perspective. Cardiovascular Research. https://doi.org/10. 1093/cvr/cvaa025

Lee, J. H., Kim, J. Y., Cho, B. B., Anusha, J. R., Sim, J. Y., Raj, C. J., \& Yu, K. H. (2019). Assessment of air purifier on efficient removal of airborne bacteria, Staphylococcus epidermidis, using single-chamber method. Environmental Monitoring and Assessment, 191, 720. https://doi.org/10. 1007/s10661-019-7876-3

Lenart-Boroń, A., Wolny-Koładka, K., Juraszek, K., \& Kasprowicz, A. (2017). Phenotypic and molecular assessment of antimicrobial resistance profile of airborne Staphylococcus spp. isolated from flats in Kraków. Aerobiologia, 33, 435-444. https://doi.org/10.1007/ s10453-017-481-7

Li, C., He, Q., Schade, J., Passig, J., Zimmermann, R., Meidan, D., Laskin, A., \& Rudich, Y. (2019). Dynamic changes in optical and chemical properties of tar ball aerosols by atmospheric photochemical aging. Atmospheric Chemistry and Physics, 19, 139-163. https://doi.org/10.5194/acp-19139-2019

Liati, A., Pandurangi, S. S., Boulouchos, K., Schreiber, D., \& Dasilva, Y. A. R. (2015). Metal nanoparticles in diesel exhaust derived by in-cylinder melting of detached engine fragments. Atmospheric Environment, 101, 34-40. https:// doi.org/10.1016/j.atmosenv.2014.11.014

Lodovici, M., \& Bigagli, E. (2011). Oxidative stress and air pollution exposure. Journal of Toxicology, 487074. DOI: https://doi.org/10.1155/2011/487074.

Maher, B. A. (2019). Airborne magnetite- and iron-rich pollution nanoparticles: potential neurotoxicants and environmental risk factors for neurodegenerative disease, including Alzheimer's disease. Journal of Alzheimer's Disease, 71, 361-375. https://doi.org/10.3233/JAD190204

Maher, B. A., Ahmed, I. A. M., Karloukovski, V., MacLaren, D. A., Foulds, P. G., Allsop, D., Mann, D. M. A., TorresJardón, R., \& Calderon-Garciduenas, L. (2016). Magnetite pollution nanoparticles in the human brain. Proceedings of the National Academy of Sciences, 113, 10797-10801. https://doi.org/10.1073/pnas.1605941113

Makonese, T., Meyer, J., \& von Solms, S. (2019). Characteristics of spherical organic particles emitted from fixed-bed residential coal combustion. Atmosphere, 10, 441. https:// doi.org/10.3390/atmos10080441

Manke, A., Wang, L., \& Rojanasakul1, Y. (2013). Mechanisms of nanoparticle-induced oxidative stress and toxicity. BioMed Research International, 942916, 15. DOI: https:// doi.org/10.1155/2013/942916.
Martinez, E. P., Cepeda, M., Jovanoska, M., Bramer, W., Schoufour, J., Glisic, M., Verbon, A., \& Franco, O. H. (2019). Seasonality of antimicrobial resistance rates in respiratory bacteria: A systemic review and meta-analysis. PLoS ONE, 14(8), e0221133. https://doi.org/10.1371/ journal.pone. 0221133

Meldunki epidemiologiczne. Zachorowania i podejrzenia zachorowań na grypę. 2020. http://wwwold.pzh.gov.pl/ oldpage/epimeld/grypa/2020/G_20_02A.pdf.

Michalik, M., Brzeżański, M., Wilczyńska-Michalik, W., Fisior, K., Klimas, B., Samek, L., \& Pietras, B. (2016). Characterisation of solid particles emitted from diesel and petrol engines as a contribution to the determination of the origin of carbonaceous particles in urban aerosol. Scientific Conference on Automotive Vehicles and Combustion Engines (KONMOT 2016) IOP Publishing IOP Conf. Series: Materials Science and Engineering, 148, 012079 doi:https://doi.org/10.1088/1757-899X/148/1/012079.

Morawska, L., Wang, H., Ristovski, Z., Jayaratne, R., Johnson, G. R., Cheung, H. C., Ling, X., \& He, C. (2009). Environmental monitoring of airborne nanoparticles. Journal of Environmental Monitoring, 11, 1758-1773. https://doi. org/10.1039/b912589m

Moriyama, M., Hugentobler, W. J., \& Iwasaki, A. (2020). Seasonality of respiratory viral infections. Annual Review of Virology, 7, 2.1-2.19. https://doi.org/10.1146/annurevvirology-012420-022445

Moteki, N., Adachi, K., Ohata, S., Yoshida, A., Harigaya, T., Koike, M., \& Kondo, Y. (2017). Anthropogenic iron oxide aerosols enhance atmospheric heating. Nature Communications, 8, 15329. https://doi.org/10.1038/ncomms15329

Nawrot, T. S., Kuenzli, N., Sunyer, J., Shi, T., Moreno, T., Viana, M., Heinrich, J., Forsberg, B., Kelly, F. J., Sughis, M., Nemery, B., \& Borm, P. (2009). Oxidative properties of ambient PM2.5 and elemental composition: Heterogeneous associations in 19 European cities. Atmospheric Environment, 43, 4595-4602. https://doi.org/10.1016/j. atmosenv.2009.06.010

Niranjan, R., \& Thakur, A. K. (2017). The toxicological mechanisms of environmental soot (Black Carbon) and Carbon Black: Focus on Oxidative Stress and inflammatory Pathways. Frontiers in Immunology, 8, 763. https://doi.org/ 10.3389/fimmu.2017.00763

Oberdörster, G. (2001). Pulmonary effects of inhaled ultrafine particles. International Archives of Occupational and Environmental Health, 74, 1-8

Oberdörster, G., Oberdörster, E., \& Oberdörster, J. (2005). Nanotoxicology: An emerging discipline evolving from studies of ultrafine particles. Environmental Health Perspectives, 113, 823-839

Oke, T. R., Mills, G., Christen, A., \& Voogt, J. A. (2017). Urban climate. Cambridge University Press.

Okochi, H., \& Brimblecombe, P. (2002). Potential trace metalorganic complexation in the atmosphere. The Scientific World Journal, 2, 767-786

Otto, M. (2017). Next-generation sequencing to monitor the spread of antimicrobial resistance. Genome Medicine, 9, 68. https://doi.org/10.1186/s13073-017-0461-x

Population. Size and structure and vital statistics in Poland by territorial division in 2018. As of December, 31. Główny Urząd Statystyczny, Warsaw 2019, 1-35. 
Pósfai, M., Gelencsér, A., Simonics, R., Arató, K., Li, J., Hobbs, P. V., \& Buseck, P. R. (2004). Atmospheric tar balls: Particles from biomass and biofuel burning. Journal of Geophysical Research, 109, D06213. https://doi.org/10. 1029/2003JD004169

Ravva, S. V., Hernlem, B. J., Sarreal, C. Z., \& Mandrell, R. E. (2012). Bacterial communities in urban aerosols collected with wetted-wall cyclonic samplers and seasonal fluctuations of live and culturable airborne bacteria. Journal of Environmental Monitoring, 14, 473-481. https://doi.org/ 10.1039/c1em10753d

Rogula-Kozłowska, W., \& Klejnowski, K. (2013). Submicrometer aerosol in rural and urban backgrounds in Southern Poland: Primary and secondary components of PM1. Bulletin of Environmental Contamination and Toxicology, 90, 103-109. https://doi.org/10.1007/s00128-0120868-4

Rogula-Kozłowska, W., Klejnowski, K., Rogula-Kopiec, P., Ośródka, L., Krajny, E., Błaszczak, B., \& Mathews, B. (2014). Spatial and seasonal variability of the mass concentration and chemical composition of PM2.5 in Poland. Air Quality, Atmosphere and Health, 7, 41-58. https://doi. org/10.1007/s11869-013-0222-y

Rogula-Kozłowska, W., Majewski, G., \& Czechowski, P. O. (2015). The size distribution and origin of elements bound to ambient particles: a case study of a Polish urban area. Environmental Monitoring and Assessment, 187, 240. https://doi.org/10.1007/s10661-015-4450-5

Ramarao, N., Tran, S. L., Marin, M., \& Vidic, J. (2020). Advanced Methods for Detection of Bacillus cereus and Its Pathogenic Factors. Sensors, 20, 2667. https://doi.org/10. 3390/s20092667

Saenen, N. D., Bové, H., Steuwe, C., Roeffaers, M. B. J., Provost, E. B., Lefebvre, W., Vanpoucke, C., Ameloot, M., \& Nawrot, T. S. (2017). Children's urinary environmental carbon load a novel marker reflecting residential ambient air pollution exposure? American Journal of Respiratory and Critical Care Medicine, 196, 873-881. https://doi.org/ 10.1164/rccm.201704-7970C

Samek, L., Stegowski, Z., Furman, L., Styszko, K., Szramowiat, K., \& Fiedor, J. (2017). Quantitative assessment of PM2.5 sources and their seasonal variation in Krakow. Water, Air and Soil Pollution, 228, 290. https://doi.org/10.1007/ s11270-017-3483-5.

Sanderson, P., Delgado-Saborit, J. M., \& Harrison, R. M. (2014). A review of chemical and physical characterisation of atmospheric metallic nanoparticles. Atmospheric Environment, 94, 353-365. https://doi.org/10.1016/j.atmosenv. 2014.05.023

Sanderson, P., Su, S. S., Chang, I. T. H., Saborit, J. M. D., Kepaptsoglou, D. M., Weber, R. J. M., \& Harrison, R. M. (2016). Characterisation of iron-rich atmospheric submicrometre particles in the roadside environment. Atmospheric Environment, 140, 167-175. https://doi.org/10. 1016/j.atmosenv.2016.05.040

Shiraiwa, M., Selzle, K., \& Pöschl, U. (2012). Hazardous components and health effects of atmospheric aerosol particles: reactive oxygen species, soot, polycyclic aromatic compounds and allergenic proteins. Free Radical Research, 46, 927-939. https://doi.org/10.3109/10715762. 2012.663084
Schraufnagel, D. E., Balmes, J. R., Cowl, C. T., De Matteis, S., Jung, S.-H., Mortimer, K., Perez-Padilla, R., Rice, M. B., Riojas-Rodriguez, H., Sood, A., Thurston, G. D., To, T., Vanker, A., \& Wuebbles, D. J. (2019). Air pollution and noncommunicable diseases. A review by the Forum of International Respiratory Societies' Environmental Committee, Part 1: The damaging effects of air pollution. Chest, 155, 409-416. https://doi.org/10.1016/j.chest.2018.10.042

Shrivastava, M., Lou, S., Zelenyuk, A., Easter, R. C., Corley, R. A., Thrall, B. D., Rasch, P. J., Fast, J. D., Simonich, S. L. M., Shen, H., \& Tao, S. (2017). Global long-range transport and lung cancer risk from polycyclic aromatic hydrocarbons shielded by coatings of organic aerosol. Proceedings of the National Academy of Sciences, 114, 1246-1251. https://doi.org/10.1073/pnas.1618475114

Sørensen, M., Schins, R. P. F., Hertel, O., \& Loft, S. (2005). Transition metals in personal samples of pm2.5 and oxidative stress in human volunteers. Cancer Epidemiology, Biomarkers and Prevention, 14, 1340-1343

Stone, V., Shaw, J., Brown, D. M., MacNee, M., Faux, S. P., \& Donaldson, K. (1998). The role of oxidative stress in the prolonged inhibitory effect of ultrafine carbon black on epithelial cell function. Toxicology in Vitro, 12, 649-659

Su, D. S., Serafino, A., Müller, J.-O., Jentoft, R. E., Schlögl, R., \& Fioriti, S. (2008). Cytotoxicity and inflammatory potential of soot particles of low-emission diesel engines. Environmental Science and Technology, 42, 1761-1765. https://doi.org/10.1021/es0716554

Tham, R., Vicendese, D., Dharmage, S. C., Hyndman, R. J., Newbigin, E., Lewis, E., O'Sullivan, M., Lowe, A. J., Taylor, P., Bardin, P., Tang, M. L. T., Abramson, M. J., \& Erbas, B. (2017). Associations between outdoor fungal spores and childhood and adolescent asthma hospitalizations. Journal of Allergy and Clinical Immunology, 139, 1140-1147. https://doi.org/10.1016/j.jaci.2016.06.046

Tóth, A., Hoffer, A., Nyirö-Kósa, I., Pósfai, M., \& Gelencsér, A. (2014). Atmospheric tar balls: aged primary droplets from biomass burning? Atmospheric Chemistry and Physics, 14, 6669-6675. https://doi.org/10.5194/acp-14-6669-2014

Valavanidis, A., Fiotakis, K., \& Vlachogianni, T. (2008). Airborne particulate matter and human health: Toxicological assessment and importance of size and composition of particles for oxidative damage and carcinogenic mechanisms. Journal of Environmental Science and Health Part C, 26, 339-362. https://doi.org/10.1080/ 10590500802494538

Wang, J., Onasch, T. B., Ge, X., Collier, S., Zhang, Q., Sun, Y., Yu, H., Chen, M., Prévôt, A. S. H., \& Worsnop, D. R. (2016). Observation of Fullerene Soot in Eastern China. Environmental Science and Technology Letters, 3, 121-126. https://doi.org/10.1021/acs.estlett.6b00044

Wawroś, A., Talik, E., Żelechower, M., Pastuszka, J. S., Skrzypek, D., \& Ujma, Z. (2003). Seasonal variation in the chemical composition and morphology of aerosol particles in the centre of Katowice, Poland. Polish Journal of Environmental Studies, 12, 619-627

Wilczyńska-Michalik, W., \& Michalik, M. (2015). Skład i pochodzenie cząstek pyłów w powietrzu atmosferycznym w Krakowie. Aura, 3, 4-8. https://doi.org/10.15199/2. 2015.3.3 
Wilczyńska-Michalik, W., Pietras, B., Samek, L., Furman, L., Łatkiewicz, A., Rzeźnikiewicz, K., \& Michalik, M. (2015). Submikronowe pyły w powietrzu atmosferycznym w Krakowie. Aura, 8, 4-7. https://doi.org/10.15199/2.2015.8. 1

Wilczyńska-Michalik, W., Rzeźnikiewicz, K., Pietras, B., \& Michalik, M. (2015). Fine and ultrafine $\mathrm{TiO}_{2}$ particles in aerosol in Kraków (Poland). Mineralogia, 45, 65-77. https://doi.org/10.1515/mipo-2015-0002

Wilczyńska-Michalik, W., Pietras, B., \& Michalik, M. (2016). Smog w Krakowie-spojrzenie w przyszłość z perspektywy historycznej. Aura, 11, 3-8. https://doi.org/10.15199/ 2.2016.11.1

Wilczyńska-Michalik, W., Gasek, R., Michalik, M., Dańko, J., \& Plaskota, T. (2018). Mineralogy, chemical composition and leachability of ash from biomass combustion and biomass-coal co-combustion. Mineralogia, 49, 67-97. https://doi.org/10.2478/mipo-2018-0008

World Urbanization Prospects. (2019). The 2018 Revision. United Nations.

Xing, J., Shao, L., Zhang, W., Peng, J., Wang, W., Shuai, S., Hu, M., \& Zhang, D. (2019). Morphology and size of the particles emitted from a GDI engine vehicle and their ageing in an environmental chamber. Atmospheric Chemistry and Physics, Discussions. https://doi.org/10.5194/acp-2019647
Zang, L., Wang, Z., Zhu, B., \& Zhang, Y. (2019). Roles of relative humidity in aerosol pollution aggravation over Central China during wintertime. International Journal of Environmental Research and Public Health, 16, 4422. https://doi.org/10.3390/ijerph16224422

Zhang, Y., Yuan, Q., Huang, D., Kong, S., Zhang, J., Wang, X., Lu, C., Shi, Z., Zhang, X., Sun, Y., Wang, Z., Shao, L., Zhu, J., \& Li, W. (2018). Direct observations of fine primary particles from residential coal burning: Insights into their morphology, composition, and hygroscopicity. Journal of Geophysical Research: Atmospheres, 123, 12964-12979. https://doi.org/10.1029/2018JD028988

Zhou, Y.-M., Zhong, C.-Y., Kennedy, I. M., Leppert, V. J., \& Pinkerton, K. E. (2003). Oxidative stress and NFB activation in the lungs of rats: a synergistic interaction between soot and iron particles. Toxicology and Applied Pharmacology, 190, 157-169. https://doi.org/10.1016/S0041008X(03)00157-1

Zuberi, B., Johnson, K. S., Aleks, G. K., Molina, L. T., \& Molina, M. J. (2005). Hydrophilic properties of aged soot. Geophysical Research Letters, 32, L01807. https://doi.org/ $10.1029 / 2004 \mathrm{~g} 1021496$

Publisher's Note Springer Nature remains neutral with regard to jurisdictional claims in published maps and institutional affiliations. 